1

2

\title{
A Brief Review of Handgrip Strength and Sport Performance
}

Authors: John Cronin ${ }^{1,5}$, Trent Lawton ${ }^{1,3}$, Nigel Harris ${ }^{1,2}$, Andrew Kilding ${ }^{1}$, Daniel Travis McMaster $^{4}$

${ }^{1}$ Sports Performance Research Institute New Zealand

AUT University

Private Bay 92006

Auckland 1020, New Zealand

${ }^{2}$ Human Potential Centre

AUT University

Private Bay 92006

Auckland 1020, New Zealand

${ }^{3}$ High Performance Sport New Zealand

Gallagher High Performance Centre

Cambridge 3494, New Zealand

${ }^{4}$ Health, Sport and Human Performance University of Waikato

Tauranga 3116, New Zealand

${ }^{5}$ School of Medical and Health Sciences Edith Cowan University

Perth, Australia

Running Title: Handgrip Strength and Force in Sport

\section{Corresponding Author:}

Daniel Travis McMaster

Health, Sport and Human Performance

University of Waikato

Tauranga 3116, New Zealand

New Zealand

+6478384466 Ext. 9476

dmcmaste@waikato.ac.nz 


\section{ABSTRACT}

2 Tests of handgrip strength (HGS) and handgrip force (HGF) are commonly used across a

3 number of sporting populations. Measures of HGS and HGF have also been utilized by

4 practitioners and researchers to evaluate links with sports performance. This article, firstly

5 evaluates the validity and reliability of various handgrip dynamometers (HGD) and HGF

6 sensors, providing recommendations for procedures to ensure precise and reliable data are

7 collected as part of an athlete testing battery. Secondly, the differences in HGS between elite

8 and sub-elite athletes and the relationships between HGS, HGF, and sports performance are

9 discussed.

KEY WORDS: Grip strength, grip force, reliability, validity, sport performance, athletes

12

\section{INTRODUCTION}

Strength and conditioning coaches are interested in measures that can objectively monitor progress and guide programming for rehabilitation and strength training of the hand, forearm and surrounding musculature. The hand is a complex anatomical system comprised of 27 bones and 15 joints with approximately 30 degrees of rotational and translational freedom designed to grasp and apply force to objects of all shapes and sizes, and perform a combination of intricate finely controlled movements (118). A number of sports where grasping and force application is important, such as baseball, climbing, golf, hockey, paddling, swimming, tennis, weightlifting and wrestling, require a sufficient, if not high degree of handgrip strength (HGS) for optimizing performance and potentially preventing injury. Practically, such measures would need to be affordable, portable, reliable and sensitive to detecting meaningful change in performance. The challenge for practitioners is to find 
1 measures that fulfil the aforementioned criteria and utilize them to guide training to a better

2 effect. One measure that may fulfil such criteria could be the use of handgrip dynamometry 3 (HGD) to measure maximum isometric HGS.

5 A number of HGD review articles have been published addressing the reliability, validity and

6 standardization of HGS testing protocols across a range of populations $(79,82,141,186)$; however, only one brief review to date has addressed the effectiveness of HGS testing in athletes (186). From a sports performance perspective it is of interest to learn how HGS relates to and effects sports specific actions and movements patterns. This review aims to, firstly provide insight into the validity and reliability of HGS and handgrip force (HGF) assessment protocols, which would aid practitioners in selecting the appropriate method and device for testing; and secondly to examine the relationships between HGS and sport performance to determine if increased HGS contributes to improved sports performance.

\section{Literature Search}

The following electronic data bases were searched: MEDLINE, EBSCO Host, Google Scholar, IngentaConnect, Ovid LWW, ProQuest Central, PubMed Central, ScienceDirect Journals, SPORTDiscus and Wiley InterScience. The following keywords were used in various combinations during the electronic searches: hand, grip, dynamometer, dynamometry, strength, force, maximum, effort, isometric, static, measure, output, quantify, assess, evaluate, test, reliability, validity, sport, athlete, performance, physical, physiological, biomechanical, 21 profile, correlation, relationship, comparison, difference, elite, novice, amatuer, and sub-elite. The searches identified 11,400 potentially relevant articles. Following a review of titles and abstracts, the total was reduced to 203. Original research articles, technical notes, and conference abstracts written in English focusing on HGD, HGS, and HGFs in all healthy 
1 elderly) were included in the initial screening phase. Final selections were based on the

2 following inclusion criteria; a) studies that reported on the reliability and validity of HGD and

3 HGS testing protocols across all healthy human population groups $(\mathrm{N}=39)$, b) studies that

4 reported the differences in HGS between elite and sub-elite athletes $(\mathrm{N}=31)$, and c) studies

5 that investigated the relationships between HGS and sport performance $(\mathrm{N}=74)$. The number

6 of articles included in this review focusing on HGS, handgrip force (HGF), and sports

7 performance are as follows: baseball $(n=18)$, basketball $(n=2)$, bowling $(n=2)$, boxing $(n=$

8 1), climbing $(n=8)$, canoe $(n=1)$, cricket $(n=3)$, equestrian $(n=2)$, field hockey $(n=3)$,

9 American football $(\mathrm{n}=3)$, European football $(\mathrm{n}=1)$, golf $(\mathrm{n}=8)$, gymnastics $(\mathrm{n}=1)$,

10 handball $(n=3)$, ice hockey $(n=3)$, judo $(n=5)$, lacrosse $(n=1)$, mountain biking $(n=1)$,

11 powerlifting $(n=1)$, rowing $(n=1)$, rugby $(n=1)$, swimming $(n=5)$, tennis $(n=9)$, volleyball $(n=3)$, waterpolo $(n=5)$, weightlifting $(n=1)$, and wrestling $(n=6)$.

\section{Data Analysis and Interpretation} 6

Interclass correlation coefficients (ICC) were reported to assess the inter-trial and inter-day reliability of a given HGD and HGS testing protocol. Pearson product moment correlations $(r)$ were reported to determine the association between HGS and sport performance. The following correlation thresholds were used to determine the reliability of the respective HGS testing protocols (ICC) and relationships to sport performance $(r)$ : trivial $(\leq 0.10)$, small (0.10-0.30), moderate (0.30-0.50), large (0.50-0.70), very large (0.70-0.90), and nearly perfect $(\geq 0.90)$ (77). Cohen's effect size calculations $\left(E S=\left[\mathrm{X}_{\text {elite }}-\mathrm{X}_{\text {sub-elite }}\right] / \mathrm{SD}_{\text {sub-elite }}\right)$ and p-values $(<0.05)$ were also used to assess the differences in HGS between elite and sub-elite athletes. ES differences were interpreted as trivial $(<0.10)$, small $(0.10-0.30)$, moderate $(0.31-0.60)$, large $(0.60-1.20)$, and very large $(>1.20)(150)$. 
PART 1. VALIDITY AND RELIABILITY OF HANDGRIP STRENGTH

2 DYNAMOMETERS AND TESTING PROTOCOLS

3

\section{Validity of handgrip strength dynamometers}

Given the various commercially available manufacturing designs and mechanisms to measure HGS (e.g. hydraulic, spring, strain gauge and pneumatic), practitioners may be concerned whether the accuracy and validity of HGD's is an adequate estimate of 'true' isometric HGS. Sealed hydraulic dynamometers measure grip force $(\mathrm{kgf})$. The pneumatic systems measure grip pressure $\left(\mathrm{mmHg}\right.$, PSI $\left[\mathrm{lbs} / \mathrm{in}^{2}\right]$, or Pascals) via the compression of air-filled compartments. Mechanical systems detect the amount of spring tension (kgf). The strain gauge systems detect changes in electrical resistance due to strain and force (Newton's) applied to the system. Electronic systems often incorporate a hydraulic dynamometer and a strain gauge to improve the accuracy of the force measurement.

\section{Calibration studies conducted by Bellace et al. (11) and Cadenas-Sanchez el al. (21) found} measurement errors of less than 1, 2, and $4 \%$ for the Jamar hydraulic, Dexter strain gauge, and TKK dynamometers, respectively. However, Shectman et al. (158) found measurement errors of 1.6 and $7.5 \%$ for DynEx and Jamar hydraulic dynamometers, respectively. They also observed force differences of 4 to $10 \%$ between the Jamar and DynEx dynamometers across a range of known loads $(9.1$ to $45.4 \mathrm{~kg})$. Dynamometer inter-changeability has been evaluated mainly by comparing the Jamar hydraulic dynamometer as the apparent 'gold standard' with newer yet to be validated dynamometers. Guerra and Amaral (65) determined that when four different devices (hydraulic, spring loaded, and pneumatic) were compared to a known laboratory standard (Jamar hydraulic dynamometer), the correlations between the criterion force (hydraulic dynamometer) and that measured by each device was found to be nearly perfect $(r>0.96)$. These findings are in agreement to previous research, where nearly perfect correlations $(r \geq 0.90)$ were also observed between hydraulic and strain gauge dynamometers 
1 (10, 111). In contrast, moderate to nearly perfect correlations $(r=0.41-0.98)$ were observed

2 between hydraulic dynamometers and various pneumatic dynamometers $(44,70,105,167)$. A

3 more recent study, found the Wii balance board to provide valid ( $r=0.80-0.88)$ measures of

4 HGS in comparison to a previously validated hydraulic dynamometer (13).

6 It is recommended that HGD's not be used interchangeably to measure and monitor HGS changes over-time $(79,140)$. Given interchangeability is not recommended, practitioners should purchase devices that remain durable for the period of any investigation required. In terms of durability, it appears that dynamometers manufactured using strain gauges may be preferable to spring-based or hydraulic pressure systems, as the latter may produce erroneous data due to wear and tear of metal, slow leaks, or hysteresis (154). This emphasizes the importance for practitioners to maintain calibration standards, with some authors recommending dynamometer calibration every 4 to 6 months to ensure longitudinal validity

14 is maintained (154).

A standardized testing position is particularly important when assessing HGS given the multiarticular functions of the hand and forearm muscles (79). Without standardization, variations in HGS may simply be related to changes in assessment protocols. The American Society of Hand Therapists recommends participants in a clinical setting are assessed sitting in a straight-back chair, with feet flat on the floor, shoulders adducted and neutrally rotated, elbow flexed at $90^{\circ}$, forearm in neutral position with the wrist self-selected between $0-30^{\circ}$ extension and between $0-15^{\circ}$ ulnar deviation (43). However, other studies:

- Found that standing produced moderately larger HGS outcomes in comparison to sitting $(E S=0.81)$; sitting produced trivial to moderately different HGS outcomes in comparison to laying supine ( $E S=-0.11$ to 0.52 ); and laying (supine and prone) had a 
very large negative effect $(E S=1.59$ and 2.17$)$ on $\mathrm{HGS}$ in comparison to standing (37, 139). These findings indicated the importance of standardizing body position and posture during HGS assessment.

- Recommend a fully extended elbow as it allows a greater HGS measure than when compared to assessments taken with the elbow flexed at $90^{\circ}(10,38,127,171)$;

- Concluded that wrist position affected HGS measurement with forearm pronation and wrist flexion producing lower values than when compared respectively to neutral or extended positions (140). It appears the optimum wrist position may be self-selected (generally $35^{\circ}$ wrist extension and $7^{\circ}$ ulnar deviation) from which any deviation appears to decrease HGS.

- Found HGS was greatest with $180^{\circ}$ of shoulder flexion (i.e. arm overhead) together with an extended elbow (171).

The reader should be cognizant that the aforementioned standardized clinical HGS testing protocols may not be appropriate and/or specific to the HGS positions and HGF requirements of sporting populations, which are subsequently addressed.

\section{Reliability of handgrip strength testing}

Once the essential body postures are clearly documented as a protocol, practitioners should ascertain other possible confounding factors warranting control or recording in notes, to stabilize interpretation of test-retest measures.

Inter-rater reliability is important when different assessors are involved in the measurement of individuals using the same device. Several studies have evaluated different assessors using identical HGS protocols, and reported very large to nearly perfect inter-rater reliability (ICC $=0.86-0.99(94,98,126,154)$. Inter-rater reliability was improved when two assessors were 
1 compared using the average of three measurements adhering to the same testing protocol.

2 However, extensive protocol training or experience may not be required as inter-rater

3 reliability did not differ notably over three consecutive trials for assessors with over 20 hours

4 or less than 5 hours of testing experience (154).

5

6 HGS test-retest reliability time-points have ranged from three hours to 12 weeks depending on the testing protocol and population of interest. Large variability in the test-retest reliability findings ( ICC $=0.48$ to 0.99 ) have been reported in the literature $(9,13,23,38,39,46,59$, $60,65,69,84,93,98,110,112,119,124,127,140,158,166,188,190)$. Given such broad ranges, it is recommended that practitioners quantify the reliability of their own assessment protocols, to gain insight as to whether procedures warrant review, or if the equipment is in need of replacing. The factors that warrant consideration when establishing a HGS protocol are summarized herewith (see Table 1):

- As it may be the case that practitioners will be monitoring small samples sizes $(\mathrm{n} \leq$ 25), a key recommendation was that at least three trials are recorded to provide better measurement reliability, irrespective of whether the maximum or mean score is examined (140). In general, the average of three measurements has proved more reliable (ICC $=0.93-0.99)$ than any single measurement $(\mathrm{ICC}=0.86-0.97)(140)$.

- It is important to standardize and provide adequate recovery between trials (1-2 $\mathrm{min})$ to minimize the effects of fatigue on HGS and maintain a high level of inter-trial reliability. Studies have reported that HGS declines with reduced inter-trial rest (15$60 \mathrm{~s}$ ) due to a lack of recovery (increase in fatigue), which could be eliminated by increasing the duration of inter-trial rest $(\geq 1 \mathrm{~min})(66,181)$. Subsequently, researchers that have adequate and clearly defined rest interval durations, reported nearly perfect inter-trial reliability $(\mathrm{ICC}=0.92-0.99)(66,145,181)$. In contrast, 
Dunwoody et al (34) implemented inter-trial rest periods of $2 \mathrm{~min}$, and found that HGS increased $(\mathrm{ES}=2.78$; very large $)$ from trial 1 to trial 4 in healthy college students, indicating a learning effect and possibly a post-activation potentiation effect. The effect post-activation potentiation protocols and inter-trial rest on HGS requires further investigation.

- It is important to standardize body and limb (segment) position across testing sessions to ensure high test-retest reliability. As discussed previously, using a seated vs. standing position, an extended vs. flexed elbow, and/or a supinated vs. pronated forearm positioning will inevitably influence $\operatorname{HGS}(37,124,125,139,140)$.

- The age and gender of participants appears to influence reliability as well as absolute HGS. When reassessed one week apart, HGS reliability in healthy 'young to middleaged' adults was very strong ( $\mathrm{ICC}=0.99)$, although slightly lower test-retest values $(r$ $=0.70$ ) have been observed in young adults aged 18-25 years (71). Similarly, very low reliability $(\mathrm{ICC}=0.48)$ was reported for adolescent girls $($ age $=13-17 \mathrm{yrs})$, in contrast their male (age $=13-17 \mathrm{yrs})$ counter-parts produced reliability $(\mathrm{ICC}=0.98)(23)$. Werle et al. (194), found a curvilinear relationship between HGS and age in a large study ( $\mathrm{n}=1023$ ) of 18 to 96 year olds, with HGS peaking in the 25 to 39 age group and declining gradually thereafter. Therefore, it is recommended that the age and gender of the sample be reported along with reliability for any established normative data.

- Similarly, it appears that occupation, leisure activity, sport, and training status may also affect HGS $(97,151)$. Josty et al. (83), for instance, reported that male office workers had significantly weaker HGS compared to equally aged car mechanics and farmers. Based on job demands, the magnitude of force required during repetitive $\mathrm{HG}$ tasks performed by a car mechanic and other physical occupations (e.g. grasping and 
lifting heavy objects, using hand-tools, such as wrenches, ratchets, saws, drills, and hammers) will differ greatly in comparison to office workers (e.g. typing, clicking a mouse, filing, and answering the phone). Schick et al. (151), also reported significantly greater HGS in boxers comparison to mixed-martial artists. Practitioners should therefore take note of the physical demands of client's or subject's occupation and sport when comparing between subject HGS as part of monitoring or intervention evaluations.

- Studies have also reported that jaw clenching, wearing a mouth guard and consuming caffeinated energy drinks significantly increases HGS (20, 54); similar HGS increases were also observed when verbal encouragement was provided $(39,130)$.

- The effect of hand dominance on HGS assessment is not straightforward; however, based on population demographic studies, most samples will be comprised of $80-90 \%$ right-hand and 10-20\% left-hand dominant individuals, respectively (81, 100). Regardless of hand dominance, researchers have found the dominant hand to be stronger, ranging from 0.1 to $16.5 \%(23,61,84)$. Nonetheless, if data is required to establish normative data for specific populations, it is recommended that practitioners note any right- and left- hand dominance in collection and subsequent analysis of data (140). It is unclear if hand dominance affects reliability; therefore we advise caution should practitioners wish to average the combined left- and right- hand measures. It is advised that data collected from both the dominant and non-dominant hands be presented to better inform the athlete and coaches of any pre-existing HGS asymmetries.

The design of device handles may also affect reliability along with HGS outputs, thus there appears need to uniformly set up devices for each participant. Most dynamometers are adjustable to the following five widths: $3.49,4.76,6.03,7.30$, and $8.57 \mathrm{~cm}$; whereas 
1 customized cylindrical strain gauge dynamometers often have differing diameters (e.g. 2.54,

$23.81,5.08,6.35$, and $7.62 \mathrm{~cm})(35)$. Studies have shown that grip widths and diameters

3 between 3.81 and $5.08 \mathrm{~cm}$ are optimal for maximizing grip strength in adults $(14,35,190)$.

4 HGS was optimized, when individuals were permitted to self-select grip-width (diameter); 46

5 and $54 \%$ of the subjects selected handgrip diameters of $4.76 \mathrm{~cm}$ (position 2) and $6.03 \mathrm{~cm}$

6 (position 3), respectively (14). Interestingly, HGS measured at a width of $10 \%$ greater (HGS

$7=44.7 \mathrm{~kg}$ ) than the self-selected $(\mathrm{HGS}=45.2 \mathrm{~kg}$ ) width was not significantly different,

8 whereas HGS was significantly reduced using widths of $10 \%$ less ( $\mathrm{HGS}=43.6 \mathrm{~kg}$ ) than the

9 self-selected width (190). Therefore, it can be inferred that a grip width of half the distance

10 between the index fingertip and the metacarpophalangeal flexion crease at the base of the

11 thumb is optimal for achieving maximum HGS. As for reliability, there does not seem to be any notable difference between retest measures if handle positions are used consistently.

13 However, the following factors should also be considered:

- HGS reliability observed for participants with a ratio showing greater length of palm

- Devices with smooth handles, such as the Jamar, may be disadvantageous for assessing grip strength of each finger, nor permit a maximal measure for participants with smaller or sensitive hands. This in part is due to the dynamometer's relatively non-adjustable and large handle positions and hard rigid grasping surface. Such factors may influence the ability for participants to reproduce maximal efforts. 


\section{Sport specific handgrip strength and force testing protocols}

2 Although it is important for clinicians to establish globally standardized HGS testing

3 procedures to ensure consistent and accurate measurements; it may also be beneficial and

4 possibly more informative to sports coaches and athletes if strength and conditioning coaches

5 and sports scientists develop sports specific HGS testing protocols. The majority of sports

6 herein have utilized one of the standardized seated or standing position HGS assessment

7 protocols (see Table 1) (43, 127). Subsequent discussions of sports specific HGS testing

8 protocols have been divided into the following four categories: 1) hand-to-projectiles, 2)

9 hand-to-implement, 3) hand-to-immovable apparatuses, and surfaces and 4) hand-to-hand

10 combat.

11 Hand-to-projectile interactions in sport

12 Hand-to-projectile interactions can be defined as any action where the hand must apply force

to an object causing projectile motion of the object, including, but not limited to, throwing

(e.g. baseball, cricket, waterpolo, handball, American football, rugby, soccer, shot putt,

discus, javelin and hammer throw), bowling (overarm and underarm), shooting (e.g. basketball and netball), and hitting (volleyball and Australian rules football). A number of these actions utilize a variation of the "precision grip" dependent on the action, size and shape of the object $(177,198)$. Intuitively assessing HGS utilizing a sports specific grip may provide a better representation of the athlete's "true" (sports specific) HGS. Tajika et al. (177) assessed handgrip and pinchgrip strength in high school baseball pitchers utilizing the standardized seated position recommended by the American Society of Hand Therapists. Considering that hand and pinch strength are relatively unrelated $\left(r^{2}=2-4 \%\right)$, the inclusion of the various pinch grips allows for a more comprehensive assessment of hand, finger and thumb strength of baseball pitchers (177). Tan et al. $(178,179)$ developed a similar and reliable protocol $(r=0.91)$ to measure Ten-pin bowling specific HGS, where only the fingers 
1 used in holding the bowling ball were tested. When compared to a conventional HGS test,

2 only a small non-significant relationship $\left(r^{2}=7 \%\right)$ was observed, which reiterates the

3 importance of developing sport and object HGS testing protocols to better inform coaches

4 and practitioners of the athlete's sport and object specific (e.g. shape, size, mass, texture and 5 density) HGS.

\section{Hand-to-implement interactions in sport}

The "power grip" is also commonly utilized in sport when gripping cylindrical shaped implements and objects, such as clubs (golf), bats (baseball, softball, cricket), rackets (tennis, badminton, squash), sticks (field hockey, lacrosse, ice hockey), bars (weightlifting, 11 powerlifting, strongman), and axes (lumberjack athletes) (198). The hand is the final link (i.e. terminal point of contact) along the kinetic chain where the generated forces and torques are transferred to the implement or object, hence the importance of handgrip function and strength to the above sports specific movements. The "power grip" more closely resembles the grip used during conventional standing and seated HGS testing protocols. One study found leather work gloves significantly reduced HGS (33 vs $43 \mathrm{kgf}$ ) in comparison to no gloves (142), which may be an important consideration for athletes that wear gloves during competition, such as golfers, baseball players and ice hockey players. One must also consider the shape, diameter, and mass of the implement, and/or object used in sport when determining how to affectively measure sports specific HGS.

To overcome the inherent limitation of maximum isometric HGS assessments, researchers have designed and examined HGF and pressure using specialized sensors during dynamic movements and sports specific actions, such as swinging a club, racket, bat, and stick $(36,89$, $90,92,95,121,123,152,170,202)$. Prior to dynamic human trials, the pressure and force 
1 sensing devices were calibrated and validated using a range of static and dynamic procedures.

2 Komi et al. (92) assessed the static and dynamic validity and reliability of the following three

3 sensors with mixed outcomes; F-Scan 9811 pressure sensors (measurement error $=6.7 \pm$

$44.8 \%$ ), flexiforce sensors (measurement error $=10.0 \pm 3.5 \%$ ), and quantum tunneling

5 composite electrodes (measurement error $=13.0 \pm 2.8 \%$ ). Data were sampled at frequencies

6 of $264 \mathrm{~Hz}, 640-1280 \mathrm{~Hz}$, and $640-1280 \mathrm{~Hz}$, respectively. Similar to the hand dynamometers,

7 a range of known loads were used to calibrate the F-Scan (pressure $=310 \mathrm{kPa}$ ), flexiforce

$8 \quad\left(\right.$ range $=0.4$ to $11.2 \mathrm{~kg} ; r^{2}=0.94$ ), and quantum tunneling composite (range $=0.4$ to $11.2 \mathrm{~kg}$;

$\left.9 \quad r^{2}=0.95\right)$ sensors. All three sensors were more accurate during the static tests (measurement

10 error $=6.7-13.0 \%$ ) in comparison to the dynamic tests (measurement error $=15-64 \%$ ).

11 Similar static validation findings using F-Scan (measurement error $=1.3-5.8 \%$ ), resistive

12 sensors (force measurement error $<2 \mathrm{~N} ; r^{2}=0.988$ ), and load cells $\left(r^{2}>0.994\right)$ were also observed $(7,17,89,90,152,202)$.

During sports specific movement trials, sensor-sampling frequencies ranged from 100 to 2900

$\mathrm{Hz}$ depending on the sensor of interest. Within and between subject reliability of HGF produced during the different sports specific movement patterns were assessed using varying sample sizes ( $\mathrm{n}=2$ to 28 ) across 4 to 32 trials depending on the study (Table 3 ). Researchers found that within-subject total $\mathrm{HGF}(\mathrm{CV}<10 \%)$, force at impact $(\mathrm{CV}<5 \%)$, and the impulse $(r=0.95)$ to be reliable during the golf swing in male and female recreational, collegiate, and professional golfers, as measured using F-scan sensors sampled at $100 \mathrm{~Hz}$ and $264 \mathrm{~Hz}$, respectively $(95,152)$. However, higher between-subject HGF variability (CV = 20-60\%) was observed throughout the phases of the golf swing; the between-subject variability was also higher during the backswing $(\mathrm{CV}=30-60 \%)$, and lower just prior to impact $(\mathrm{CV}=20-30 \%)$. In varsity and professional tennis players, Knudson and White (90) observed poor within- 
1 subject $\mathrm{HGF}$ reliability at impact $(\mathrm{CV}=27 \pm 9 \%)$, and post-impact $(\mathrm{CV}=69 \pm 44 \%)$ when

2 returning balls fired at $20 \mathrm{~m} / \mathrm{s}$ from a ball machine. Knudson (89) also observed less within-

3 subject variability in pre-impact $(\mathrm{CV}=13-27 \%)$ and post-impact $(\mathrm{CV}=15-29 \%)$ HGF during

4 the one-handed backhand stroke under a similar testing protocol. Similarly, poor between-

5 subject HGF reliability was observed in cricket batting pre-impact (CV $=31-32 \%)$, on-impact

$6 \quad(\mathrm{CV}=23-51 \%)$, and post-impact $(\mathrm{CV}=20-41 \%)$ with the ball bowled at a medium-fast pace;

7 the within-subject reliability was not reported (169). Interestingly and as expected, HGF

8 produced by skilled-elite $(\mathrm{CV}=23 \pm 8 \%)$ tennis players' were larger and less variable than

9 their less skilled-subelite $(\mathrm{CV}=33 \pm 7 \%)$ counterparts.

The above observations indicate that the within-subject HGF produced during the golf swing are less variable and more reliable than the forehand and backhand tennis strokes in part due to the reactive nature of tennis (i.e. making contact with a moving object) in comparison to the non-reactive nature of golf (i.e. hitting a stationary ball). Another possible explanation is that larger vibration forces are experienced by the hands during a tennis stroke because of the length discrepancy between tennis rackets and golf clubs. Detailed analyses and interpretation of handgrip force-time signatures using accurate pressure and force sensors during dynamic sports specific actions could greatly improve current HGF diagnostics to optimize sport performance.

\section{Hand-to-immovable apparatus or surface interactions in sport}

22 High relative HGS and HGS endurance is required for climbing and gymnastics, where the athlete is moving his or her body around an immovable apparatus (e.g. rock-wall, mountain, parallel bars, uneven bars, and the pummel horse) for an extended period of time. A number of rock climbing studies have assessed maximum HGS (ICC $=0.93-0.96)$ and HGS 
1 endurance (ICC $=0.86-0.92$ ) from a hanging position with the elbows flexed at $90^{\circ}$ and with

2 the elbows fully extended overhead $(5,9,102)$. Balas et al. (9) observed moderate $(r=0.49)$

3 and very large $(r=0.72)$ correlations between conventional HGS and hanging HGS

4 endurance in elite male and female rock climbers, respectively. These highly reliable rock

5 climbing specific maximum HGS and HGS endurance testing protocols can be implemented

6 as possible indicators of rock-climbing ability, as discussed in the following section (Part 2).

7 Amca et al. (5) developed laboratory based protocols similar to the previously mentioned

8 hanging position utilizing a wall mounted force plate to measure maximum force (vertical,

9 and antero-posterior) generated during rock-climbing specific grips (half-crimp and crimp

10 grip); however, the reliability of these protocol were not reported. Detailed biomechanical

11 assessments of hand and finger forces produced during climbing specific grips (e.g. crimp and

12 slope grips) have also been measured using high frequency sampling (1024 Hz) strain gauge

technology in trained climbers; the reliability of these assessments were not reported (135,

14 155). No research to date has been conducted on HGF measures during climbing and/or

gymnastics events.

\section{Hand-to-hand combat}

In hand-to-hand combat sports, such as wrestling, judo, jiu-jitsu, and mixed martial arts, maximum HGS is important when pushing, pulling, throwing and controlling your opponent. Possessing a high level of HGS endurance is also believed to be important, if, and when the match/fight progresses into the later rounds $(15,30,48)$. Therefore, it is recommended to include measures of maximum HGS and HGS endurance in the physical assessment battery of hand-to-hand combats sports. Hanging position HGS endurance protocols using judogi and kimono sleeves (ICC > 0.98) have been utilized in Judo (judokas) and Jiu Jitsu athletes to better assess sports specific HGS endurance of these two disciplines (45, 48). Bonitch- 
1 Góngora et al. (15) implemented a novel HGS fatigue (endurance) protocol in judo athletes

2 using the conventional position recommended by the American Society of Hand Therapist

3 (43), where the athletes completed 8 consecutive maximum isometric contractions of $10 \mathrm{~s}$

4 with a 10 s rest between contractions. Significant reductions $(p=0.000)$ in HG torque were

5 observed between the first and eighth contraction in elite male $(E S=2.12)$ and female $(E S=$

6 1.38) judo athletes. Dias et al. (30) also implemented a similar protocol consisting of a $10 \mathrm{~s}$

7 maximum isometric contraction utilizing a strain gauge dynamometer to measure peak force,

8 time-to-peak force, impulse and fatigue in highly trained judokas. Judo combat can be

9 characterized as a high-intensity intermittent sport requiring a combination of maximum

10 strength and endurance during grip combat, where the ability to rapidly obtain and sustain a

11 strong grip and pull or push the opponent is a desired attribute in judo athletes. A valid $(r=$ 0.78) and reliable ( $\mathrm{ICC}=0.97)$ judo specific maximum $\mathrm{HG}$ pulling force protocol has also been developed using a specialized strain gauge, where the athletes gripped a judogi sleeve in a standing position with shoulder adducted, the elbow flexed at $90^{\circ}$ and the forearm in a neutral position $(29,72)$. While this is a measure of pulling strength and not a direct measure of HGS, the hand is only point of contact to apply and transfer force to the judogi sleeve. Again, no research to date has been conducted on HGF measures during any hand-to-hand combat sports.

\section{Handgrip strength assessment recommendations}

In summary, a variety of HGD's, strain gauges, and pressure sensors are available to practitioners to measure and monitor HGS and HGF under isometric and dynamic conditions. As dynamometers differ in manufacturing design, they produce different absolute measurements and therefore should not be used interchangeably. The reliability of HGS measures is dependent on the maintenance and calibration of the dynamometer; therefore, the servicing of equipment should be carefully considered and implemented by the practitioner. If 
1 various practitioners are to be involved in assessing participants, the inter-rater reliability for any protocol should be reported, and protocols refined.

4 A summary of HGS testing protocols is provided in Table 1, however we recommend practitioners consider the following and establish their own test-retest reliability for assessing

6 HGS :

- The posture and position of shoulder, elbow, forearm and wrist are accurately described and replicated on each test occasion.

- At least three trials are performed with rest intervals of at least one-minute.

- Re-test reliability is assessed over three separate sessions, and examined using either the peak or average of the three trials of each testing occasion.

- The age, gender, hand-dominance, anthropometrics, and sport demographics of participants are reported along with ICC or test-retest correlations.

- The HG width setting chosen is noted along with the dynamometers specifications and manufacturer details.

- Conditions associated with testing such as participant observation, encouragement, nutrition or environment, are reported.

HGS dynamometry, as with any assessment tool, requires rigid adherence to protocols to provide robust and reliable performance monitoring.

\section{INSERT TABLE 1 ABOUT HERE}

More advanced laboratory based handgrip testing protocols have also been utilized to affectively assess isometric and dynamic HGF and torque in athletes $(4,33,66,68,84,89$, 178). HGF testing protocols using specialized force and pressure sensors have also been 
1 implemented to accurately measure and monitor HGF during sports specific actions, such as

2 swinging a club, bat, stick, or racket (Table 2). However, dynamic HGF protocols using

3 advance technology may be less viable and practical than the previously mentioned protocols

4 using commercially available HGD.

5

INSERT TABLE 2 ABOUT HERE

\section{PART 2: HANDGRIP STRENGTH AND SPORT PERFORMANCE}

Clinically, the function, assessment and rehabilitation of the hand and forearm are wellresearched areas; however, the second part of this article will focus primarily on the relationship and effects of HGS to sport and athlete performance. During a number of sport specific movements, the hand is the only point of physical contact between the athlete and the implement and/or object, hence the functional importance of the hand to sport performance (198, 202). Young (198), describes and illustrates the differences between the "precision grip" used for grasping sphere shaped objects (e.g. balls) and the "power grip" used for grasping cylindrical shaped objects (e.g. clubs, bats, rackets, sticks and paddles). The majority of sports specific actions involving the hand utilize the precision grip, power grip, or a variation of these grips. HGS is believed to be an important attribute for throwing (e.g. baseball, softball, cricket, American football, European football, rugby, handball, water polo, javelin, hammer throw, discus, and shot put), bowling (i.e. overhand and underhand), punching, clinching, and grappling in hand-to-hand combat sports, paddling (e.g. row, canoe, and kayak), and swinging a racket, stick, bat, or club (e.g. cricket, baseball, golf, tennis, squash, lacrosse, field hockey and, ice hockey) $(61,66,127,163,173,200,202)$. Other sports requiring a sufficient to high level of HGS may include: basketball, volleyball, rock climbing, swimming, sailing, 
1 riding/driving (e.g. horses, bulls, mountain bikes, motorcycles, and racecars), and strength

2 athletes (e.g. weightlifting, powerlifting, and strongman).

4 On review of the available HGS literature at publication, the authors observed that some 5 sports such as baseball, golf, climbing, swimming, water polo, wrestling, judo, handball, and 6 tennis have had more research attention. In contrast, other sports where HGS is also believed to play a role in performance had minimal research attention, such as paddling sports (e.g. kayaking, rowing, and canoeing), hockey (ice and field), basketball, volleyball, riding (horses,

9 bulls, bikes, and motorcycles), and driving (race cars). Due to the lack of studies investigating the relationship between HGS and performance in a number of sports, making definitive 11 conclusions and recommendations for practitioners is problematic. Furthermore, there is a lack of longitudinal interventions constraining interpretations about causal relationships between training methods to improve HGS and performance outcomes. However, the studies presented in Tables 3 and 4, provide evidence to support, as well as refute the importance of and relationships between HGS and sport performance.

A large number of studies found that elite and successful athletes possessed greater HGS in comparison to their sub-elite and less successful counterparts (Table 3) supporting the relationship (Table 4) between HGS and the level of sporting ability $(15,28,33,52,55,56$, $63,87,129,143,159)$. In contrast, some studies found minimal differences in HGS between elite and sub-elite athletes $(27,109,132,136,148,157,199)$. However, closer examination of the included studies has provided some clarity and revealed a number of trends between HGS and performance across a range of sports. Subsequent discussions have been organized according to sport type as follows: 1) stick, club, bat, racket, and ball sports, 2) water sports, 3) climbing and gymnastics, 4) combat sports, and 5) strength disciplines. 


\section{INSERT TABLE 4 ABOUT HERE}

\section{Handgrip Strength in Stick, Club, Bat, Racket and Ball Sports}

This section will focus primarily on the relationships between HGS and the following sports specific actions: throwing (overhand and underhand) and bowling (overhand and underhand) a ball and swinging a stick, club, bat and racket. Trivial to nearly perfect correlations were observed between HGS and throwing velocity $(r=0.22-0.62)$, throwing energy (0.89-0.91), cricket bowling accuracy $(r=0.03)$, ten-pin bowling accuracy $(r=-0.12-0.27)$, bat, club, and stick/puck speed $(r=0.31-0.85)$, bat energy $(r=0.88-0.90)$, fielding percentage $(r=-0.09)$, and golf, field hockey, ice hockey, and lacrosse shot accuracy $(r=-0.11-0.36)(3,4,6,16,18$, $31,51,73,78,106,107,120,134,138,164,165,172,176,178,179,189,192,193,202)$.

These findings suggest that HGS is more closely related to rotational movements requiring high torque, work and velocity generating abilities; whereas movements requiring a high amount of technical precision and accuracy appear to be less related to HGS. Similarly, once a threshold of HGS is attained, further competitive advantage may not be gained where the coordination and timing (e.g. bat, club, stick, and racket sports) of skilled actions is more important (174).

A number of studies also found other measures of upper and lower strength (e.g. shoulder rotation, torso rotation, lower back, chest, back squat, hang clean, pull-up, bent-over row, cable woodchop, and bench press), ballistic ability (e.g. medicine ball chest pass, rotational medicine ball throw, vertical, and lateral jumps), technical ability (e.g. shoulder, elbow and 
1 body mass, and lean body mass) to have moderate to nearly perfect associations ( $r=0.34$ -

2 0.95) with overhand bowling (cricket), throwing (baseball and softball), and bat and club

3 velocity $(3,16,50,62,73,74,86,96,101,103,117,134,137,172,173,176,192,193,197)$.

4 It also appears that increased HGS is associated with greater upper strength, ballistic 5 performance $(r=0.65)$, body mass $(r=0.50)$, lean body mass $(r=0.56-0.57)$, and height $(r=$ $6 \quad 0.33)$ across a number of these sports $(91,129,149,177)$.

A comparison of professional baseball players revealed trivial and moderate non-significant HGS differences between the Major League Baseball (MLBC) and minor league baseball ("AAA" and "AA") players, respectively; whereas, moderate and large significant differences were observed between MLB players in comparison to "A" and rookie league players, respectively (76). Possibly indicating that there are minimal difference in HGS between the various groups of professional baseball players; where as a between study comparison revealed very large $(E S=2.16-4.77)$ differences in HGS between professional and amateur baseball players $(76,199)$. A similar trend was also observed in ice-hockey players; where elite collegiate male hockey players produced significantly larger HGS in comparison to subelite collegiate players. The elite players were also significantly taller and heavier, which may have contributed to the differences in HGS (129). Trivial to very large correlations were observed between HGS and shot (wrist and slap) velocity in male and female hockey players $(4,202)$. Alexander et al. (4) observed that body mass $(r=0.48)$ was more closely associated with slap shot velocity than HGS $(r=0.25)$ in elite male ice-hockey players. In support of the notion that HGS plays a role in shot velocity, Zane (202) observed that players with a high slap-shot velocity produced significantly greater HGS in comparison to their low-velocity counterparts. 
1 A limited number of studies have investigated the effects of HGS training interventions on

2 sports specific actions, such as throwing and swinging, therefore it is difficult to draw any

3 definitive conclusions. However, two studies investigating the effects of resistance training

4 supplemented with HGS and forearm training over 12 weeks found significantly greater

5 improvements in forearm and HGS than the resistance training only group (175); similar

6 moderate improvements in bat swing velocity (3.2 and 3.5\%) were observed in both training

7 groups (174). This indicates that performing additional resistance training designed to

8 increase forearm and HGS did not further enhance bat-swing velocity in high school baseball

9 players. Furthermore, an 8-week bat swing training study using a dynamic moment of inertia

10 bat designed to reduce the moment of inertia during the initial stage of the swing, lead to

11 significantly greater improvements in bat velocity (6.2\%) in comparison to training with a standard bat $(-2.1 \%)(99)$. Of note, 8 -weeks of inertia bat training lead to trivial reductions $(E S=-0.09)$ in right HGS and moderate improvements $(E S=0.44)$ in left HGS, respectively; whereas, the standard bat training lead to large reductions $(E S=-0.68$ and -0.74$)$ in right- and left- HGS. In summary, resistance training without additional HGS training is an effective means of improving HGS and bat swing velocity concurrently in high school baseball players; whereas, rotational inertia bat swing training is 2-fold more effective than resistance training at increasing bat swing velocity in baseball players. Other hand-to-implement sports, such as tennis, squash, and badminton could also potentially benefit from rotational velocity specific training using specialized equipment.

\section{Handgrip Strength in Court Sports}

Court sports where hand function and arguably HGS are of importance, include racket sports lacrosse. In the majority of court sports, high torque and rotational velocity of the shoulder, 
1 arm, and wrist during overarm movements are desired attributes and a requirement for

2 generating greater ball release velocities (185). Wagner et al. (185) observed that the overarm

3 movements of serving a tennis ball, spiking a volleyball, and throwing a handball have similar

4 but not identical proximal-to-distal sequencing of joint kinematics throughout the phases (i.e.

5 cocking, accelerating and follow through), indicating that there is a general motor pattern in

6 overarm movements. Hence the similar associations with the various predictive variables;

7 such as moderate to very large correlations were observed between HGS, and ball/racket

8 velocities during serving in tennis and volleyball players $(r=0.30-0.66)$, and throwing

9 velocity in handball $(r=0.50-0.68)(24,114,133,161,182,203)$. These findings further

10 support the notion that HGS is an important attribute for athletes performing high rotational

11 torque actions, such as overarm throwing, serving, and spiking actions, where the successful

action of serving a volleyball and/or tennis ball depends on height of contact, ball direction (i.e. projection and trajectory), and release velocity .

Volleyball and handball playing ability $(r=0.78-0.90)$, and tennis ranking $(r=0.67-0.80)$ also appear to be strongly associated with HGS, sprint acceleration, jumping ability, and motor coordination $(61,114,131,132,162)$, with the exception of Roetart et al. (144) whom found a trivial relationship between tennis ranking and HGS in junior male tennis players. To further support these relationships, elite handball athletes produced significantly greater HGS $(\mathrm{MDiff}=30 \%)$ and muscle mass $(\mathrm{MDiff}=17 \%)$ in comparison to their sub-elite counterparts (109). HGS is less of a discriminator between elite and sub-elite junior court based athletes, as may be expected based on the similarities in body mass and, in turn, muscle mass between elite and sub-elite youth athletes $(132,183)$. 
1 Other strength (e.g. bench press strength and wrist, elbow, shoulder, and knee torque),

2 ballistic (e.g. medicine ball throw distance, and bench throw velocity, and power), flexibility

3 (e.g. shoulder and wrist), and anthropometric (e.g. body mass, lean mass, height, and arm

4 span) measures were also moderately to very largely correlated $(r=0.31-0.85)$ with serving,

5 spiking, and throwing velocity in tennis, volleyball, and handball athletes, respectively (24,

$626,114,128,160,203)$. This indicates that multiple regression analyses that include two or

7 more of the key variables (e.g. anthropometric, flexibility, strength, and ballistic ability)

8 provide better predictive ability of serving and throwing velocity, as opposed to a single

9 variable $(24,26,132)$.

11 HGS was also found to be very largely correlated with free throw shooting accuracy $(r=$ 0.76) of semi-professional basketball players in a non-fatigued state; however, in a fatigued state (post-training) a non-significant relationship was observed (104). The authors suggest this was due to varying within group adaptations to training load, which was likely due to individual variations in fitness and recovery rates. With the exception of the above study, movements and actions requiring a high amount of precision and accuracy appear to be less related to HGS, such as points/game and assists/game in basketball (113), or tennis stroke technique and accuracy (i.e. service, forehand, backhand, down line, cross-court, and serve placement $)(128,144)$. Shot accuracy and precision in tennis players was more closely associated ( $r=0.34-0.57)$ with other strength measures, such as knee and shoulder torque (128). 
2 Field sports, where hand function is of importance include field hockey (i.e. passing and

3 shooting), field lacrosse (i.e. defending, passing and shooting), rugby (i.e. passing, gripping,

4 fending and tackling), Australia Rules Football, Gaelic Football, American football (throwing, 5 gripping, fending and tackling) and European football (i.e. during the throw-in and for the

6 keeper). In field sports, the hand applies a gripping force to the implement (i.e. stick), object 7 (i.e. ball) or body (i.e. opposition) for the purpose of holding or restraining, which is often a 8 quasi-dynamic or an isometric application of HGF. Anecdotally, grasping and holding a stick 9 or object in sport will require less HGF in comparison to the HGF required for gripping, 10 holding, restraining and/or tackling an opposing player. However, there is minimal HGF 11 research on field sport specific actions to support these claims. In contact field sports, such as American football, moderate to very large differences $(E S=$ $0.47-1.10)$ were observed between elite and sub-elite male athletes $(159,168)$. Straub (168) overall strength should also possess greater HGS. also observed significantly larger HGS in the older more experienced professional players (age $=28 \mathrm{yrs}$ ) in comparison to the younger less experienced collegiate players (age $=20 \mathrm{yrs}$ ). Williford et al. (195) also observed that heavier linemen possessed much greater levels of overall strength $(E S=1.10-1.94)$ than the lighter backs. Similarly, older and heavier professional rugby league players possessed significantly greater overall strength $(E S=1.78)$ in comparison to the younger lighter sub-elite state league players (8). Based on the positive associations ( $r=0.46-0.58)$ between HGS and overall strength and body mass in rugby and American football athletes (180), it can be inferred that field sport athletes possessing greater 4 
1 The strength differences within a homogenous group of professional athletes appears to be 2 much less. Shields et al. (159) investigating the strength differences within a team of

3 professional American football players found small to moderate non-significant differences in 4 HGS and overall strength (i.e. upper and lower body strength) between veteran starters and 5 non-starters. To further support these findings, trivial to small negative and positive 6 correlations were observed between HGS and player rankings within samples of collegiate and professional American football teams; indicating that HGS is unrelated to playing performance within a given cohort of American football athletes (168). These findings are also in agreement with trends observed in elite male field hockey players and professional male baseball players $(76,157)$. As expected, other performance markers, such as sprinting, change-of-direction, and aerobic capacity were unrelated to HGS in field sport athletes $(r=-0.11$ to 0.16$)$; with the exception of a group of adolescent (age $=11-17$ yrs) European football players (80). In this study, sprint and change-of-direction ability were significantly correlated with HGS, and the majority of physical performance measures were significantly correlated with age. These findings indicate HGS may be a covariate of overall physical ability and age in developing youth athletes.

A number of actions performed in field sports (i.e. passing, throwing, and shooting) also require high torques and rotational (angular) velocities for generating greater ball release velocities. During these actions, the hand is the terminal point (i.e. last point) of contact along the kinetic chain just prior to release or impact, therefore optimal function of the hand is vital to applying force and pressure to the implement or ball in their execution (198). The timing and sequencing of the applied force during these actions is arguably more important than the maximum amount of HGF an athlete can generate. The low correlations observed between 
1 maximum HGS and passing and shooting accuracy in field sports, reinforces the notion that

2 HGS is not the determining factor in highly coordinated skilled actions $(107,157,189)$.

\section{Handgrip forces in action}

The coordination, timing and sequencing of force, and pressure applied by the hand to an object (i.e. ball), or implement (i.e. bat, stick, racket, or club) during the various stages of a given sports specific movement pattern (i.e. swinging an implement and/or throwing an object) is fundamental to understanding the importance of the hand to sports performance. The laws of linear, angular, and projectile motion state that angular velocity, point of contact or point/height of release, impact force, release trajectory, and linear release velocity are the key performance indicators for swinging an implement and throwing an object. Accurate assessment of handgrip forces along with other kinematic (i.e. angular acceleration and angular velocity) and kinetic (i.e. torque) variables contributing to the resultant performance indicators are key to understanding the mechanisms of these actions. Based on the handgrip force-time signatures during the golf swing, cricket bat swing, baseball bat swing, hockey slap-shot and wrist-shot, and tennis forehand, and backhand, the following trends were observed $(17,19,36,90,92,95,152,169,202)$ :

- Low total handgrip forces were applied during the backswing

- High total handgrip forces were applied during the acceleration phase

- Reduced total handgrip forces at impact

- A spike in force occurring immediately prior to and a second spike in force occurring immediately post-impact (with the exception of cricket batting)

Furthermore, the amount of force and pressure used to grip a ball, stick, racket, club, bat, bar, disc, or handle is inversely proportional to wrist range of motion; and in turn the amount of applied force varies throughout the stages of a given movement pattern. This mechanical 
1 relationship between force application and joint range-of-motion during complex dynamic movements in sport may help explain the conjecture in the literature regarding the relationship between isometric HGS and sports performance. This information suggests that the timing and sequencing of the force applied to an implement or object by the hand (palm, digits, and thumb) in sport is of greater importance than the magnitude of applied force alone.

\section{Handgrip Strength in Water Sports}

In water sports, the hand is often directly (i.e. swimming) or indirectly (i.e. gripping a paddle, oar, or rudder) the last bodily point of contact within the kinetic chain propelling oneself through the water; hence the importance of the hand to performance in most, if not all, water sports. In competitive swimmers, trivial non-significant to very large significant correlations were observed between HGS and freestyle swim performance (12, 25, 32, 57, 58, 147, 200).

The majority of these participants were comprised of competitive youth and teenage athletes (82\%). In light of these mixed findings, stronger correlations were observed between HGS and sprint swim performance $(r=0.18-0.82$; distance $\leq 100 \mathrm{~m})$ in comparison to swim endurance performance $(r=0.01-0.65$; distance $\geq 200 \mathrm{~m})$ in youth and teenage swimmers. To further reinforce the notion a regression analysis revealed that HGS may have a greater contribution to sprint swim performance, Zampagni et al. $(200,201)$ found HGS explained $52 \%$ of the variance in $50 \mathrm{~m}$ freestyle swim performance and only $15 \%$ of the variance in $800 \mathrm{~m}$ swim performance of elite male and female masters swimmers $(\mathrm{n}=135)$. Therefore,

21 HGS could possibly be used as an affective sprint distance performance predictor in competitive masters' swimmers. Based on the physical characteristics of swimmers it has been suggested that maximum HGS along with other upper and lower body strength measures play a greater role in sprint swim versus endurance swim performance (58). Other single and multiple (combined) measures of strength (e.g. tethered swim force, upper arm, shoulder, and 
1 abdominal flexion) along with horizontal jump performance, aerobic, and anaerobic capacity,

2 anthropometry (e.g. height, arm span, and foot length), and flexibility (ankle and shoulder

3 range of motion) are of equal or greater importance to predicting swim performance (i.e. via

4 linear and multivariate regression analyses) in adolescent, teenage and adult swimmers (32, 5 147, 200).

7 It is also suspected that HGS would also play a part in a number of other water sport 8 disciplines such as, surfing, kayaking, canoeing, paddle boarding, rowing, whitewater slalom 9 (canoe and kayak), and sailing. In support of this claim, Secher (156) reported a significant 10 correlation $(r=0.44)$ between HGS and rowing performance, as well as a very large 11 significant difference in HGS between elite international and club level male rowers. Hamano et al. (68) also found that HGS was largely to very largely correlated with average power during 2 min maximum effort canoe and kayak ergometer sprints in elite flatwater canoers $(r$ $14=0.75)$ and kayakers $(r=0.65)$, respectively. Large to very large correlations were also observed between kayak/canoe ergometer performance and a number of anthropometric measures (e.g. body mass, lean muscle mass, and chest, waist, and arm girth), bench press strength, and lower body knee extension torque. These findings further reinforce the notion that possessing the aforementioned anthropometric and physical performance qualities are beneficial to excelling in water sports.

There is a sufficient volume of research investigating the relationships between HGS and throwing velocity in water polo athletes $(1,40-42,108)$. Water polo can be described as a contact team sport with an emphasis on swimming, jumping, throwing, blocking, pushing and holding (42). The overhand throwing action used for $90 \%$ of all passes and shots in water polo is similar to that of other throwing sports (e.g. handball, baseball, and cricket). The main 
1 point of difference is that water polo athletes must generate the majority of their force and torque with their upper body as opposed to land based sports where force is transferred from

3 the ground through the kinetic chain. Moderate to large correlations were observed between

4 HGS and throwing velocity in elite water polo athletes, accounting for 13 to $36 \%$ of the

5 variance in throwing velocity $(1,40-42)$. The findings indicate that certain anthropometric 6 characteristics $(r=0.68-0.95)$, such as limb length, height, lean muscle mass, and 7 somatotype along with throwing technique may be greater predictors of throwing velocity in water polo athletes $(1,41,42)$. No water sport HGS comparative studies (elite vs. sub-elite) were available.

\section{Handgrip Strength in Climbing and Gymnastics}

Athletes partaking in climbing and gymnastics (i.e. rings and bars) arguably require a high amount of relative HGS and HGS endurance to successfully compete in their respective disciplines. Limited research is available on HGS and performance in gymnastics athletes; however, one study found very large correlation $(r=0.81)$ between HGS and HGS endurance in ring athletes (146). Due to the limited number of articles published on gymnastics athletes, subsequent discussions will focus on climbing athletes. In climbers, large to very large correlations were observed between maximum relative HGS (i.e. HGS relative to body mass), crimp grip strength, pinch grip strength, and rock climbing ability $(r=0.55-0.94)(9,53$, $116,191)$.

Following a similar trend to previous sections, climbing performance is related to the interactions of multiple variables (e.g. upper and lower body strength, anthropometry, body composition and flexibility) rather than a single predictive measure $(115,116,187)$. Studies comparing elite to sub-elite adult male rock climbers observed large to very large differences 
$1 \quad(E S=1.20-3.86)$ in HGS between groups $(9,64)$. More pronounced HGS differences were

2 observed between elite and sub-elite female rock climbers $(E S=2.00-4.90)$, while similar

3 differences were also observed between elite and sub-elite female athletes in other sports (i.e.

4 field hockey, judo, and ten-pin bowlers) $(9,15,63,87,136,148,179,187)$. Based on the

5 correlation and comparative findings, there is strong evidence to suggest that possessing a

6 high amount of relative HGS is advantageous to competing and excelling in the sport of 7 climbing as well as gymnastics (i.e. rings and bars).

\section{Handgrip Strength in Combat Sports}

Success in combat sports, such as boxing, mixed martial arts and wrestling is multifaceted and requires high levels of technical, tactical, physical and psychological ability to compete and excel at any level $(47,148)$; and cannot be predicted by a single physical parameter. Franchini et al. (49) found no significant relationships between HGS and technical actions (e.g. throws, holds, locks or chokes) in elite judokas. Opposing this finding, moderate and very large relationships have been observed between HGS and wrestling success $(r=0.41)$ and boxing competition ranking $(r=0.87)$, respectively $(66,122)$. In support of the positive relationship between HGS and combat sport performance, a pooled effect size comparison of elite to subelite athletes indicates that elite male athletes possess higher HGS in comparison to their subelite counterparts $(E S=0.91)$. Furthermore, elite adult male wrestlers $(E S=1.17)$ and judokas $(E S=2.23-3.07)$ produced much larger HGS in comparison to sub-elite adult male wrestlers and judokas $(33,122)$. These elite combat sport athletes also possessed greater overall strength (i.e. bench press, squat and pull-up strength) and ballistic abilities (i.e. vertical jump, horizontal jump, sprinting, and shot putt performance); further supporting the notion that HGS is a covariate of overall strength. 
1 Similarly, junior male high school wrestlers with a high winning percentage possessed

2 significantly greater HGS $(E S=3.33)$ than wrestlers with a low winning percentage (143).

3 The pooled data also suggests that HGS has a large positive effect $(E S=0.70)$ on wrestling

4 and judo performance in junior male athletes. However, the high variability in the magnitude

5 of differences ( $E S_{\text {range }}=-0.61$ to 0.83 ) in HGS between studies comparing elite to sub-elite

6 junior male combat sport athletes provides some evidence to refute the importance of HGS to

7 performance $(15,27,28,55,148)$. Demirkan et al. (27) observed trivial to moderate non-

8 significant HGS differences between junior male (age $=16.2-16.7$ yrs) elite and sub-elite

9 wrestlers. Sanchez et al. (148) also observed trivial to moderate non-significant HGS

10 differences between gold, silver, bronze, and non-medaling junior male (age = $15-19$ yrs)

11 judokas, whereas Garcia-Pallares et al. (55) using a slightly older cohort of junior male

12 wrestlers (age $=17.5-19.6$ yrs), found that the elite wrestlers exhibited moderate non-

13 significant to largely significant greater HGS capabilities versus their sub-elite counterparts.

14 These findings suggest that the magnitude of difference in HGS between elite and sub-elite

adult male wrestlers and judokas is larger than the HGS differences in junior elite and subelite male wrestlers and judokas. A possible explanation for this phenomenon could be that the differences in overall strength (i.e. maximum upper and lower body strength) between the elite and sub-elite athletes within the junior male population is less than the overall strength differences within the adult male population.

The differences in HGS between elite and sub-elite female combat sport athletes was more pronounced than their male counterparts. A pooled effect size analysis revealed very large HGS differences $(E S=1.57)$ between elite and sub-elite junior female wrestlers and judokas $(15,56,148)$. The accentuated HGS differences between elite and sub-elite combat sport 
1 athletes within the female population may be in part attributed to the differences in age, overall strength and training experience (56).

4 Following a similar trend to the previously discussed sports and athletic disciplines, combat sport studies have observed moderate to very large overall strength differences between elite and sub-elite combat sports athletes $(27,55,56,122)$. Additionally, there are moderate to very large relationships between combat sport performance and other strength $(r=0.40)$, anaerobic $(r=0.65-0.91)$, aerobic $(r=0.81)$, and body composition $(r=-0.70$ to -0.87$)$ measures $(49,66,122)$. In summary, elite combat sport athletes appear to possess greater overall maximum strength, explosive strength, lower body fat percentages, and greater aerobic and anaerobic capacity in comparison to amateur and sub-elite combat sport athletes.

\section{Handgrip Strength in Strength Athletes}

The literature indicates that there is a strong linear relationship between maximum HGS and maximum upper and lower body strength in non-strength sport athletes. This relationship in strength athletes is subsequently discussed. Athletes participating in the following disciplines are classified as strength athletes: Olympic weightlifters, powerlifters, and strongman competitors. Schoffstall et al. (153) observed nearly perfect correlations ( $r \geq 0.97)$ between HGS and powerlifting strength (i.e. bench press, squat and deadlift) in male and female raw competitive powerlifters; whereas small to moderate correlations ( $r=0.31-0.41)$ were observed between HGS and powerlifting strength in equipped powerlifters (i.e. permitted to wear wrist wraps, knee wraps and supportive powerlifting suits). It appears that HGS is a good indicator of total strength in competitive raw powerlifters, but not equipped powerlifters.

The importance of HGS in equipped powerlifting is likely reduced due to the use of wrist wraps, knee wraps and powerlifting suits designed to better stabilize the athlete during the 
1 various lifts; whereas in raw powerlifting wraps and suits are not permitted likely increasing

2 the HGS demands during the respective lifts. A relatively small sample size was used in this

3 study; therefore, caution is advised when interpreting these relationships.

In support of these relationships, Fry et al. (52) observed large differences in HGS (ES = 0.93) between elite and sub-elite junior Olympic weightlifters. The elite group was also more impulsive (i.e. vertical jump) and stronger across all lifts (i.e. snatch, clean and jerk, front squat, back squat and bench press). The above study, suggests that a regression analysis incorporating the following testing battery, vertical jump ability, HGS, body composition, flexibility, and kinesthetic awareness can be used to accurately differentiate elite from subelite junior male weightlifters. These findings align with previous recommendations, in that multiple regression analyses that include two or more important dependent variables will provide a more accurate and informative prediction of athletic ability. Of note, the elite junior lifters herein possessed strength levels $($ clean $=125 \mathrm{~kg}$, back squat $=173 \mathrm{~kg}$, bench press $=$ $111 \mathrm{~kg}$ ) similar to that of adult male team sport athletes. Caution must be advised when interpreting these findings, as only a small cohort of strength athletes were examined due to the lack of current research examining HGS in strength athletes.

\section{CONCLUSION}

A HGD, as with any assessment tool, requires rigid adherence to clinical, practical, and/or newly developed sports specific HGF and pressure testing protocols to provide robust and reliable monitoring of athletes. Based on the large number of HGS studies discussed in this review, key generalizations, and sports specific recommendations for strength and conditioning coaches have been provided. 
1 In general, HGS appears to be an attribute of elite athletes and a covariate of overall upper

2 and lower body strength, impulsive ability (i.e. sprinting and jumping), body mass, lean

3 muscle mass, age and training experience (i.e. training age). HGS also seems to be related to

4 movement patterns (i.e. most rotational movements) that utilize the kinetic chain (i.e. the

5 summation of forces and torques initiated and distributed in sequence from large to small

6 muscle groups) to generate large torques and angular velocities, where the hand is the

7 terminal (i.e. last) point of contact prior to impact and/or release. Furthermore, the timing and

8 sequencing of the force applied to an implement (i.e. bat, stick, club, racket and bar) or object

9 (i.e. ball) by the hand in sport is arguably of greater importance than the magnitude of applied

10 force alone. The transfer of force and torque during any complex kinetic chain movement

11 sequence is dependent on several factors including technique (i.e. coordination and 12 sequencing), strength, anthropometry and flexibility.

13 By way of contrast, movement patterns requiring a high degree of accuracy and relatively low release velocities are poorly related to maximum isometric HGS. These movement patterns may include but are not limited to shooting and passing accuracy, chipping and putting 16 accuracy, tennis stroke placement, fielding performance (i.e. baseball and cricket) and bowling score. Similarly, once a threshold of HGS is attained, such as within a group of elite athletes, further competitive advantage may not be gained in sports where timing (e.g. bat, club, stick and racket sports) and/or the scoring of skilled maneuvers is part of the technical and tactical strategy (e.g. judo, wrestling, boxing and mixed martial arts) (179). It is also not surprising that aerobic fitness measures share less common variance with HGS, as remarkable muscle mass is not observed or needed in sports requiring such attributes.

In summary, HGS training is conceivably of importance to enhancing the performance of a number of gross motor movement patterns in sports and athletic disciplines involving the 
1 hand. By simply increasing overall upper and lower body strength and increasing muscle

2 mass through various resistance-training interventions, an athlete's maximum isometric HGS

3 should increase. However, improving an athletes ability to effectively apply force to an

4 object or implement during a given sport specific movement pattern is multifactorial. These

5 factors include technical ability (i.e. movement coordination, sequencing and timing),

6 physical capacity (i.e. strength, flexibility, neuromuscular function and reaction time), body

7 composition anthropometry, and tactical ability (i.e. reading and reacting to the opposition).

8 Therefore, it is recommended that the sport scientist, strength and conditioning coach and

9 technical (i.e. skills) coach:

10 - Identify the key physical, technical and tactical factors that determine proficiency and 11 mastery of a given movement pattern;

- Develop a specific battery of tests to effectively measure and monitor improvements in these key factors;

- Train the key movement patterns and muscles groups to improve and master a given sports specific movement pattern.

\section{Acknowledgements}

No sources of funding were used to assist in the preparation of this review.

\section{Conflicts of Interest}

The authors have no potential conflicts of interest that are directly related to the content of this review.

\section{References}


1. Abraldes J, Canossa S, Soares S, Fernandes R, and Garganta J. Relationship between hand grip strength and shot speed in different competitive level water polo players, in: National Strength and Conditioning Association International Conference. San Antonio, Spain, 2014, p S143.

2. Agbuga B, Konukman F, and Yilmaz I. Prediction of upper body strength by using grip strength test in division II American college football players' grip strength. Hac J Sport Sci 20: 16-23, 2009.

3. Albert J, Szymanski D, and Standley B. Relationship between changes in physiological characteristics and softball- specific variables of NCAA division I softball players. J Strength Cond Res 22: 83-84, 2008.

4. Alexander J, Haddow J, and Schultz G. Comparison of the ice hockey wrist and slap shots for speed and accuracy. Res Q Ex Sport 34: 259-266, 1963.

5. Amca AM, Vigouroux L, Aritan S, and Berton E. Effect of hold depth and grip technique on maximal finger forces in rock climbing. J Sports Sci 30: 669-677, 2012.

6. Amritashish B and Shiny R. Anthropometric and physical variables as predictors of off-spin performance in cricket: a multiple regression study. Int J Sports Sci Fit 5; 314-322, 2015.

7. Bachus KN, DeMarco AL, Judd KT, Horwitz DS, and Brodke DS. Measuring contact area, force, and pressure for bioengineering applications: using Fuji Film and TekScan systems. Med Eng Phys 28: 483-488, 2006.

8. Baker DG and Newton RU. Comparison of lower body strength, power, acceleration, speed, agility, and sprint momentum to describe and compare playing rank among professional rugby league players. J Strength Cond Res 22: 153-158, 2008.

9. Balas J, Pecha O, Martin A, and D. C. Hand-arm strength and endurance predictors of climbing performance. Eur J Sport Sci 12: 16-25, 2012.

10. Beaton DE, O'Driscoll SW, and Richards RR, Grip strength testing using the BTE work simulator and the Jamar dynamometer: a comparative study. Baltimore Therapeutic Equipment. J Hand Surg 20: 293-298, 1995.

11. Bellace JV, Healy D, Besser MP, Byron T, and Hohman L. Validity of the Dexter Evaluation System's Jamar dynamometer attachment for assessment of hand grip strength in a normal population. $J$ Hand Ther 13: 46-51, 2000.

12. Blanksby B, Bloomfield J, Ponchard M, and Ackland TR. The relationship between anatomical characteristics and swimming performance in state age group championship competitors. J Swim Res 2: 30-36, 1986.

13. Blomkvist AW, Andersen S, de Bruin ED, and Jorgensen MG. Isometric hand grip strength measured by the Nintendo Wii Balance Board - a reliable new method. BMC Musculo Dis 17: 56, 2016.

14. Boadella JM, Kuijer PP, Sluiter JK, and Frings-Dresen MH. Effect of self-selected handgrip position on maximal handgrip strength. Arch Phys Med Rehab 86: 328-331, 2005.

15. Bonitch-Góngora JG, Almeida F, Padial P, Bonitch-Domínguez JG, and Feriche B. Maximal isometric handgrip strength and endurance differences between elite and non-elite young judo athletes. Sci Mar Arts 9: 239-248, 2013.

16. Bonnette R, Spaniol F, Melrose D, Ocker L, Paluseo J, and Szymanski D. The relationship between rotational power, bat speed, and batted-ball velocity of NCAA division I baseball players J Strength Cond Res 22: 112-113, 2008.

17. Broker JP and Ramey MR. A new method for measuring grip force and its distribution during the golf swing. Annual Rev Golf Coach: 121-134, 2007.

18. Brown SJ, Nevill AM, Monk SA, Otto SR, Selbie WS, and Wallace ES. Determination of the swing technique characteristics and performance outcome relationship in golf driving for low handicap female golfers. J Sports Sci 29: 1483-1491, 2011. 
19. Budney D and Bellow D. Evaluation of golf club control by grip pressure measurement

3 in: Science and Golf. London: E \& FN Spon, 1990 pp 30-35. clenching while wearing a customized bite-aligning mouthpiece on strength in healthy young men. J Strength Cond Res 30: 1102-1110, 2016.

21. Cadenas-Sanchez C, Sanchez-Delgado G, Martinez-Tellez B, Mora-Gonzalez J, Lof M, Espana-Romero V, Ruiz JR, and Ortega FB. Reliability and validity of different models of tkk hand dynamometers. Am J Occ Ther 70: 1-9, 2016.

22. Chidley JB, MacGregor AL, Martin C, Arthur CA, and Macdonald JH. Characteristics explaining performance in downhill mountain biking. Int J Sports Physiol Perf 10: 183-190, 2015.

23. Clerke AM, Clerke JP, and Adams RD. Effects of hand shape on maximal isometric grip strength and its reliability in teenagers. J Hand Ther 18: 19-29, 2005.

24. Cohen DB, Mont MA, Campbell KR, Vogelstein BN, and Loewy JW. Upper extremity physical factors affecting tennis serve velocity. Am J Sports Med 22: 746-750, 1994.

25. Dalamitros AA, Manou V, and Pelarigo JG. Laboratory-based tests for swimmers: methodology, reliability, considerations and relationship with front-crawl performance. $J$ Hum Sport Ex 9: 172-187, 2014.

26. Debanne $\mathrm{T}$ and Laffaye G. Predicting the throwing velocity of the ball in handball with anthropometric variables and isotonic tests. J Sports Sci 29: 705-713, 2011.

27. Demirkan E, Koz M, Kutlu M, and Favre M. Comparison of physical and physiological profiles in elite and amateur young wrestlers. J Strength Cond Res 29: 1876$1883,2015$.

28. Demirkan E, Unver R, Kutlu M, and Koz M. The comparison of physical and physiological characteristics of junior elite wrestlers. University J Physical Ed Sport Sci 6: 138-144, 2012.

29. Detanico D, Arins FB, Pupo JD, and Santos SGD. Strength parameters in judo athletes: An approach using hand dominance and weight categories. Hum Mov 13: 330-336, 2012.

30. Dias JA, Wentz M, Kulkamp W, Mattos D, Goethel N, and Junior NB. Is the handgrip strength performance better in judokas than in non-judokas? Sci Sports 27: e9-14, 2012.

31. Doan BK, Newton RU, Kwon YH, and Kraemer WJ. Effects of physical conditioning on intercollegiate golfer performance. J Strength Cond Res 20: 62-72, 2006.

32. Douda HT, Toubekis AG, Georgio C, Gourgoulis V, and Tokmakidis SP. Predictors of performance in pre-pubertal and pubertal male and female swimmers. Presented at International Symbosium on Biomechanics and Medicine in Swimming, Oslo, Norway, 2010. 33. Drid P, Casals C, Mekic A, Radjo I, Stojanovic M, and Ostojic SM. Fitness and anthropometric profiles of international vs. national judo medalists in half-heavyweight category. J Strength Cond Res 29: 2115-2121, 2015.

34. Dunwoody L, Tittmar HG, and McClean WS. Grip strength and intertrial rest. Percept Motor Skills 83: 275-278, 1996.

35. Edgren CS, Radwin RG, and Irwin CB. Grip force vectors for varying handle diameters and hand sizes. Hum Factors 46: 244-251, 2004.

36. Eggeman GW and Noble ML. Design and testing of a baseball- bat transducer. Exp Tech 9: 20-23, 1985.

37. El-Sais WM and Mohammad WS. Influence of differeent testing postures on hand grip strength. Eur Sci J 10: 290-301, 2014. 

JR. Elbow position affects handgrip strength in adolescents: validity and reliability of Jamar, DynEx, and TKK dynamometers. J Strength Cond Res 24: 272-277, 2010.

39. Essendrop M, Schibye B, and Hansen K. Reliability of isometric muscle strength tests for the trunk, hands and shoulders. Int J Ind Erg 28: 379-387, 2001.

40. Ferragut C, Abraldes J, Manchado C, and Vila H. Water polo throwing speed and body composition: an analysis by playing positions and opposition level. J Hum Sport Ex 10: 81-94, 2015.

41. Ferragut C, Abraldes J, Vila H, Rodriguez N, Argudo F, and Fernandes R. Anthropometry and throwing velocity in elite water polo by specific playing positions. J Hum Kinet 27: 31-44, 2011.

42. Ferragut C, Vila H, Abraldes J, Argudo F, Rodriguez N, and Alcaraz PE. Relationship among maximal grip, throwing velocity and anthropometric parameters in elite water polo players. J Sports Med Phys Fit 51: 26-32, 2011.

43. Fess EE and Moran CA. Grip Strength, in: Clinical Assessment Recommendations Chicago: American Society of Hand Therapists, 1992.

44. Fike M and Rousseau E. Measurement of adult hand strength: a comparions of two instruments. Occup Ther J Res 2: 43-49, 1982.

45. Follmer B, Dellagrana RA, Franchini E, and Diefenthaler. Relationship of kimono grip strength tests with isokinetic parameters in jiu-jitsu athletes. Braz J Kinanthrop Hum Perform 17: 575-582, 2015.

46. Fong PW and Ng GY. Effect of wrist positioning on the repeatability and strength of power grip. Am J Occ Ther 55: 212-216, 2001.

47. Franchini E, Del Vecchio FB, Matsushigue KA, and Artioli GG. Physiological profiles of elite judo athletes. Sports Med 41: 147-166, 2011.

48. Franchini E, Miarka B, Matheus L, and Vecchio FBD. Endurance in judogi grip strength tests: comparison between elite and non-elite judo players. Sci Mar Arts 7: 1-4, 2011. 49. Franchini E, Takito MY, and Bertuzzi RCM. Morphological, physiological and technical variables in high-level college judoists. Sci Mar Arts 1: 1-7, 2005.

50. Freeston JL, Carter T, Whitaker G, Nicholls O, and Rooney KB. Strength and power correlates of throwing velocity on subelite male cricket players. J Strength Cond Res 30: 1646-1651, 2016.

51. Fry A, Honnold D, Hudy A, Roberts C, Gallagher P, Vardiman P, and Dellasega C. Relationships between muscular strength and batting performances in collegiate baseball athletes. J Strength Cond Res 25: 19-20, 2011.

52. Fry AC, Ciroslan D, Fry MD, LeRoux CD, Schilling BK, and Chiu LZ. Anthropometric and performance variables discriminating elite American junior men weightlifters. J Strength Cond Res 20: 861-866, 2006.

53. Gajeswski J, Hubner-Woziak E, Tomaszewski P, and Sienkiewicz-Dianzenza E. Changes in handgrip force and blood lactate as response to simulated climbing competition. Biol Sport 26: 14-21, 2009.

54. Gallo-Salazar C, Areces F, Abian-Vicen J, Lara B, Salinero JJ, Gonzalez-Millan C, Portillo J, Munoz V, Juarez D, and Del Coso J. Enhancing physical performance in elite junior tennis players with a caffeinated energy drink. Int J Sports Physiol Perf 10: 305-310, 2015.

55. Garcia-Pallares J, Lopez-Gullon JM, Muriel X, Diaz A, and Izquierdo M. Physical fitness factors to predict male Olympic wrestling performance. Eur J Appl Physiol 111: 1747-1758, 2011. 

fitness factors to predict female Olympic wrestling performance and sex differences. $J$ Strength Cond Res 26: 794-803, 2012. specific parameters: A cross-sectional study on maximum handgrip isometric strength. Percept Motor Skills 114: 936-948, 2012.

58. Geladas ND, Nassis GP, and Pavlicevic S. Somatic and physical traits affecting sprint swimming performance in young swimmers. Int J Sports Med 26: 139-144, 2005.

59. Gerodimos V. Reliability of handgrip strength test in basketball players. J Hum Kinet 31: 25-36, 2012.

60. Gerodimos V and Karatrantou K. Reliability of maximal handgrip strength test in prepubertal and pubertal wrestlers. Pediatr Exerc Sci 25: 308-322, 2013.

61. Girard O and Millet GP. Physical determinants of tennis performance in competitive teenage players. J Strength Cond Res 23: 1867-1872, 2009.

62. Gordon BS, Moir GL, Davis SE, Witmer CA, and Cummings DM. An investigation into the relationship of flexibility, power, and strength to club head speed in male golfers. $J$ Strength Cond Res 23: 1606-1610, 2009.

63. Grant S, Hasler T, Davies C, Aitchison TC, Wilson J, and Whittaker A. A comparison of the anthropometric, strength, endurance and flexibility characteristics of female elite and recreational climbers and non-climbers. J Sports Sci 19: 499-505, 2001.

64. Grant S, Hynes V, Whittaker A, and Aitchison T. Anthropometric, strength, endurance and flexibility characteristics of elite and recreational climbers. J Sports Sci 14: 301-309, 1996.

65. Guerra RS and Amarla TF. Comparison of hand dynamometers in elderly people. $J$ Nut Health Age 13: 907-912, 2009.

66. Guidetti L, Musulin A, and Baldari C. Physiological factors in middleweight boxing performance. J Sports Med Phys Fit 42: 309-314, 2002.

67. Gurer B and Yildiz M. Investigation of sport rock climbers' handgrip strength. Biol Ex 11: 55-71, 2015.

68. Hamano S, Ochi E, Tsuchiya Y, Muramatsu E, Suzukawa K, and Igawa S. Relationship between performance test and body composition/physical strength characteristic in sprint canoe and kayak paddlers. J Sports Med 6: 191-199, 2015.

69. Hamilton A, Balnave R, and Adams R. Grip strength testing reliability. J Hand Ther 7: 163-170, 1994.

70. Hamilton GF, McDonald C, and Chenier TC. Measurement of grip strength: validity and reliability of the sphygmomanometer and jamar grip dynamometer. J Orthop Sports Phys Ther 16: 215-219, 1992 .

71. Haward BM and Griffin MJ. Repeatability of grip strength and dexterity tests and the effects of age and gender. Int Arch Occup Environ Health 75: 111-119, 2002.

72. Heinisch HD, Knoll K, Kindler M, and Haupt H. Development and evaluation of a judo-specific grip strength-test. Presented at International Judo Research Symposium, Rio de Janeiro, 2013.

73. Heitman RJ, Pugh SF, Erdmann JW, and Kovaleski JE. Measurement of upper and lower body strength and its relationship to underhand pitching speed. Percept Motor Skills 90: 1139-1144, 2000.

74. Hellstrom J. The relation between physical tests, measures, and clubhead speed in elite golfers. Int J Sports Sci Coach 3: 85-92, 2008.

75. Hobbs SJ, Baxter J, Broom L, Rossell LA, Sinclair J, and Clayton HM. Posture, flexibility and grip strength in horse riders. J Hum Kinet 42: 113-125, 2014. 
76. Hoffman JR, Vazquez J, Pichardo N, and Tenenbaum G. Anthropometric and performance comparisons in professional baseball players. J Strength Cond Res 23: 2173$2178,2009$.

77. Hopkins WG. Linear models and effect magnitudes for research, clinical and practical applications. Sportsci 14: 49-57, 2010.

78. Hughes SS, Lyons BC, and Mayo JJ. Effect of grip strength and grip strengthening exercises on instantaneous bat velocity of collegiate baseball players. J Strength Cond Res 18: 298-301, 2004.

79. Innes E. Handgrip strength testing: a review of the literature. Aust Occup Ther J 46: 120-140, 1999.

80. James RS, Thake CD, and Birch S. Relationships between measures of physical fitness change when age dependent bias is removed in a group of young male soccer players. J Strength Cond Res Ahead of Print, 2016.

81. Johnston DW, Nicholls ME, Shah M, and Shields MA. Nature's experiment? Handedness and early childhood development. Demography 46: 281-301, 2009.

82. Jones LA. The assessment of hand function: a critical review of techniques. $J$ Hand Surg 14: 221-228, 1989.

83. Josty IC, Tyler MP, Shewell PC, and Roberts AH. Grip and pinch strength variations in different types of workers. J Hand Surg Br 22: 266-269, 1997.

84. Kamimura $\mathrm{T}$ and Ikuta $\mathrm{Y}$. Evaluation of grip strength with a sustained maximal isometric contraction for 6 and 10 seconds. J Rehab Med 33: 225-229, 2001.

85. Keeton S. Fitness level and success in female intercollegiate equestrian athletes, in: Science in Health Promotion. Oklahoma: Oklahoma State University, 2005.

86. Keogh JW, Marnewick MC, Maulder PS, Nortje JP, Hume PA, and Bradshaw EJ. Are anthropometric, flexibility, muscular strength, and endurance variables related to clubhead velocity in low- and high-handicap golfers? J Strength Cond Res 23: 1841-1850, 2009.

87. Keogh JW, Weber CL, and Dalton CT. Evaluation of anthropometric, physiological, and skill-related tests for talent identification in female field hockey. Can J Appl Physiol 28: 397-409, 2003.

88. Kilic I and Binboga M. Investigation of structural and biomotoric features of young volleyball players and determining the position by discriminant analysis. Sci Mov Health 12: 142-153, 2012.

89. Knudson D. Forces on the hand in the tennis one-handed backhand. Int J Sport Biomech 7: 282-292, 1991.

90. Knudson DV and White SC. Forces on the hand in the tennis forehand drive: Application of force sensing resistors. Int J Sport Biomech 5: 324-331, 1989.

91. Koley S, Yadav M, and Sandhu J. Estimation of hand grip strength and its association with some anthropometric traits in cricketers of amritsar, punjab, india. Internet J Biol Anthropol 3: 1-7, 2008.

92. Komi E, Roberts J, and Rothberg S. Evaluation of thin, flexible sensors for timeresolved grip force measurement. J Mech Eng Sci 221: 1687-1699, 2008.

93. Kramer JF, Nusca D, Bisbee L, MacDermid J, Kemp D, and Boley S. Forearm pronation and supination: reliability of absolute torques and nondominant/dominant ratios. $J$ Hand Ther 7: 15-20, 1994.

94. Lagerstrom C and Nordgren B. On the reliability and usefulness of methods for grip strength measurement. Scandinavian Journal of Rehabilitation Medicine 30: 113-119, 1998.

95. Langlais SM and Broker JP. Grip pressure distributions and associated variability in golf: a two-club comparison. Sports Biomech 13: 109-122, 2014.

96. Lewis AL, Ward N, Bishop C, Maloney S, and Turner AN. Determinants of club head speed in PGA professional golfers. J Strength Cond Res 30: 2266-2270, 2016. 
2 Hand-grip strength of young men, women and highly trained female athletes. Eur $J$ Appl 3 Physiol 99: 415-421, 2007.

4 98. Lindstrom-Hazel D, Kratt A, and Bix L. Interrater reliability of students using hand 5 and pinch dynamometers. Am J Occ Ther 63: 193-197, 2009. of inertia bat on swing performance. J Strength Cond Res 25: 2999-3005, 2011.

100. Llaurens V, Raymond M, and Faurie C. Why are some people left-handed? an evolutionary perspective. Philos Trans Royal Soc B 364: 881-894, 2009.

101. Loock H, Grace J, and Semple S. Association of selected physical fitness parameters with club head speed and carry distance in recreational golf players. Int J Sports Sci Coach 8: 769-777, 2013.

102. Lopez-Rivera E, Jose J, and Gonzalez-Badillo JJ. The effects of two maximum grip strength training methods using the same effort duration and different edge depth on grip endurance in elite climbers. Sports Tech 5: 100-110, 2012.

103. Lowe H, Szymanski DJ, Bankston BL, Braswell MT, Britt AT, Gilliam ST, Herring AL, Holloway BT, Lowe DW, Potts JD, Szymanski JM, and Till ME. Relationship between body composition and bat swing velocity of college softball players. J Strength Cond Res 24, 2010.

104. Lupo C. Anthropometric, strength, session-RPE, and shoot performance evaluations in sub-elite male italian basketball players. Ital J Anat Emb 120: 204, 2015.

105. Lusardi MM and Bohannon RW. Hand grip strength: comparability of measurements obtained with a Jamar dynamometer and a modified sphygmomanometer. $J$ Hand Ther 4: 117-122, 1991.

106. Mangine GT, Hoffman JR, Vazquez J, Pichardo N, Fragala MS, and Stout JR. Predictors of fielding performance in professional baseball players. Int $J$ Sports Physiol Perf 8: 510-516, 2013.

107. Marsh DW, Richard LA, Verre AB, and Myers J. Relationships among balance, visual search, and lacrosse-shot accuracy. J Strength Cond Res 24: 1507-1514, 2010.

108. Martinez JG, Vila MH, Ferragut C, Noguera MM, Abraldes JA, Rodriguez N, Freeston J, and Alcaraz PE. Position-specific anthropometry and throwing velocity of elite female water polo players. J Strength Cond Res 29: 472-477, 2015.

109. Massuca LM, Fragoso I, and Teles J. Attributes of top elite team-handball players. $J$ Strength Cond Res 28: 178-186, 2014.

110. Massy-Westropp N, Rankin W, Ahern M, Krishnan J, and Hearn TC. Measuring grip strength in normal adults: reference ranges and a comparison of electronic and hydraulic instruments. J Hand Surg 29: 514-519, 2004.

111. Mathiowetz V. Comparison of Rolyan and Jamar dynamometers for measuring grip strength. Occup Ther Int 9: 201-209, 2002.

112. Mathiowetz V, Weber K, Volland G, and Kashman N. Reliability and validity of grip and pinch strength evaluations. J Hand Surg 9: 222-226, 1984.

113. McGill SM, Andersen JT, and Horne AD. Predicting performance and injury resilience from movement quality and fitness scores in a basketball team over 2 years. $J$ Strength Cond Res 26: 1731-1739, 2012.

114. Melrose D, Bohling M, Spaniol F, and Bonnette R. Physiological and performance characteristics of adolescent club volleyball players J Strength Cond Res 20: e20, 2006.

115. Mermier CM, Janot JM, Parker DL, and Swan JG. Physiological and anthropometric determinants of sport climbing performance. Br J Sports Med 34: 359-365; discussion 366, 2000 . 
116. Mitchell AC, Bowhay A, and Pitts J. Relationship between anthropometric characteristics of indoor rock climbers and top roped climbing performance. J Strength Cond Res 25: S94-95, 2011.

4 117. Miyaguchi K and Demura S. Relationship between upper-body strength and bat swing

118. Moran CA. Anatomy of the hand. Phys Ther 69: 1007-1013, 1989.

119. Murugan S, Pate D, Prajapati K, Ghoghari M, and Patel P. Grip strength changes in relation to different body postures, elbow and forearm positions. Int J Physiother Res 1: 116$121,2013$.

120. Nakata H, Nagami T, Higuchi T, Sakamoto K, and Kanosue K. Relationship between performance variables and baseball ability in youth baseball players. J Strength Cond Res 27: 2887-2897, 2013.

121. Nikonovas A, Harrison AJ, Hoult S, and Sammut D. The application of force-sensing resistor sensors for measuring forces developed by the human hand. J Eng Med 218: 121-126, 2004.

122. Nikooie R, Cheraghi M, and Mohamadipour F. Physiological determinants of wrestling success in elite Iranian senior and junior Greco-Roman wrestlers. J Sports Med Phys Fit, 2015.

123. Noble L and Eggeman GW. Baseball bat instrumentation for the measurement of hand forces. J Biomech 15: 341, 1982.

124. Oxford KL. Elbow positioning for maximum grip performance. $J$ Hand Ther 13: 3336, 2000.

125. Parvatikar VB and Mukkannavar PB. Comparative study of grip strength in different positions of shoulder and elbow with wrist in neutral and extension positions. $J$ Ex Sci Physiother 5: 67-75, 2010.

126. Peolsson A, Hedlund R, and Oberg B. Intra- and inter-tester reliability and reference values for hand strength. Journal of Rehabilitation Medicine 33: 36-41, 2001.

127. Pereira HM, Menacho MO, Takahashi RH, and Cardoso JR. Handgrip strength evaluation on tennis players using different recommendations. Braz J Sports Med 17: 184$188,2011$.

128. Perry AC, Wang X, Feldman BB, Ruth T, and Signorile J. Can laboratory-based tennis profiles predict field tests of tennis performance? J Strength Cond Res 18: 136-143, 2004.

129. Peterson BJ, Fitzgerald JS, Dietz CC, Ziegler KS, Ingraham SJ, Baker SE, and Snyder EM. Division I hockey players generate more power than division III players during on- and off-ice performance tests. J Strength Cond Res 29: 1191-1196, 2015.

130. Peynircioglu ZF, Thompson JL, and Tanielian TB. Improvement strategies in freethrow shooting and grip-strength tasks. J Gen Psych 127: 145-156, 2000.

131. Phulkar A. Relationship of selected strength and flexibility measures to playing ability in handball. Int J Health Sports Phys Ed 2: 24-26, 2014.

132. Pion JA, Fransen J, Deprez DN, Segers VI, Vaeyens R, Philippaerts RM, and Lenoir M. Stature and jumping height are required in female volleyball, but motor coordination is a key factor for future elite success. J Strength Cond Res 29: 1480-1485, 2015.

133. Pugh SF, Kovaleski JE, Heitman RJ, and Gilley WF. Upper and lower body strength in relation to ball speed during a serve by male collegiate tennis players. Percept Motor Skills 97: 867-872, 2003.

134. Pugh SF, Kovaleski JE, Heitman RJ, and Pearsall AW. Upper and lower body strength in relation to underhand pitching speed by experienced and inexperienced pitchers. Percept Motor Skills 93: 813-818, 2001. 
135. Quaine F and Vigouroux L. Maximal resultant four fingertip force and fatigue of the extrinsic muscles of the hand in different sport climbing finger grips. Int J Sports Med 25: 634-637, 2004. characteristics of tenpin bowlers with different playing abilities. Biol Sport 29. 33-38, 2012

137. Read PJ, Lloyd RS, De Ste Croix M and Oliver JL. Relationships between field-based measures of strength and power and golf club head speed. J Strength Cond Res 27: 27082713, 2013.

138. Reed J, Szymanski D, Albert J, Hawthorne D, Hsu HS, Skinner C, and Tatum J. Relationship between physiological performance variables and baseball/softball specific variables of novice college students. J Strength Cond Res 22: 111-112, 2008.

139. Richards LG. Posture effects on grip strength. Arch Phys Med Rehab 78: 1154-1156, 1997.

140. Richards LG, Olson B, and Palmiter-Thomas P. How forearm position affects grip strength. Am J Occ Ther 50: 133-138, 1996.

141. Roberts HC, Denison HJ, Martin HJ, Patel HP, Syddall H, Cooper C, and Sayer AA. A review of the measurement of grip strength in clinical and epidemiological studies: towards a standardised approach. Age Ageing 40: 423-429, 2011.

142. Rock KM, Mikat RP, and Foster C. The effects of gloves on grip strength and threepoint pinch. J Hand Ther 14: 286-290, 2001.

143. Roemmich JN and Frappier JP. Physiological determinants of wrestling success in high school athletes. Pediatr Exerc Sci 5: 134-144, 1993.

144. Roetert EP, Garrett GF, Brown SW, and Camaione DN. Performance profiles of nationally ranked junior tennis players. J App Sport Sci Res 6: 225-231, 1992.

145. Ruiz-Ruiz J, Mesa JL, Gutierrez A, and Castillo MJ. Hand size influences optimal grip span in women but not in men. J Hand Surg 27: 897-901, 2002.

146. Ruprai RK, Tajpuriya SV, and Mishra N. Handgrip strength as determinant of upper body strength/physical fitness: a comparative study among individuals performing gymnastics (ring athletes) and gymnasium (powerlifters). Int J Med Sci Pub Health 5: 1167-1171, 2016.

147. Saavedra JM, Escalante Y, and Rodriguez FA. A multivariate analysis of performance in young swimmers. Pediatr Exerc Sci 22: 135-151, 2010.

148. Sánchez AG, Domínguez AS, Turpin JAP, Tormo JMC, and Llorca CS. Importance of hand-grip strength as an indicator for predicting the results of competitions of young judokas. Sci Mar Arts: 3, 2011.

149. Sathya P, Kadhiravan V, Ramakrishnan K, and Ghodake A. Association between hand grip strength and shoulder power in intercollegiate cricket players. Int J Innov Res Sci Eng Tech 5: 3085-3091, 2016.

150. Saunders PU, Pyne DB, Telford RD, and Hawley JA. Reliability and variability of running economy in elite distance runners. Med Sci Sports Exerc 36: 1972-1976, 2004.

151. Schick MG, Brown L, Coburn J, Beam W, Schick E, and Dabbs C. Physiological profile of mixed martial artists. Medicina Sportiva 14: 182-187, 2010.

152. Schmidt E, Roberts J, and Rothberg S. Time-resolved measurements of grip force during a golf shot. Eng Sport 6, 2006.

153. Schoffstall J, Morrison SD, Kozlik B, and Boswell B. Grip strength and powerlifting performance, in: Southeastern Chapter of the American College of Sports Medicine Regional Conference. 2010.

154. Schreuders T, A. R., Roebroeck M, E. , Goumans J, van Nieuwenhuijzen JF, Stijnen $\mathrm{TH}$, and Stam HJ. Measurement error in grip and pinch force measurements in patients with hand injuries. Physical Therapy 83: 806, 2003. 
155. Schweizer A. Biomechanical properties of the crimp grip position in rock climbers. $J$ Biomech 34: 217-223, 2001.

3 156. Secher NH. Isometric rowing strength of experienced and inexperienced oarsmen.

$4 \quad$ Med Sci Sports 7: 280-283, 1975.

5 157. Sharma A, Tripathi V, and Koley S. Correlations of anthropometric characteristics 2012.

158. Shechtman O, Gestewitz L, and Kimble C. Reliability and validity of the DynEx dynamometer. $J$ Hand Ther 18: 339-347, 2005.

159. Shields CL, Jr., Whitney FE, and Zomar VD. Exercise performance of professional football players. Am J Sports Med 12: 455-459, 1984.

160. Singh AB and Behera S. Relationship of anthropometric characteristics and kinematic variables with spiking of volleyball players. J Ed Prac 4: 165-171, 2013.

161. Smart J, McCurdy K, Miller B, and Pankey R. The effect of core training on tennis serve velocity. J Strength Cond Res 25: S103-104, 2013.

162. Smith DJ, Roberts D, and Watson B. Physical, physiological and performance differences between Canadian national team and universiade volleyball players. J Sports Sci 10: 131-138, 1992.

163. Spaniol F. Baseball athletic test: a baseball specific test battery. Strength Cond $J$ 31: 26-29, 2009.

164. Spaniol F, Bonnette R, and Melrose D. Physiological predictors of bat speed and batted-ball velocity in NCAA division I baseball players J Strength Cond Res 20: e25, 2006.

165. Spaniol F, Bonnette R, and Melrose D. The relationship between grip strength and bat speed of adolescent baseball players J Strength Cond Res 21: e19-20, 2007.

166. Stephens JL, Pratt N, and Michlovitz S. The reliability and validity of the Tekdyne hand dynamometer: Part II. J Hand Ther 9: 18-26, 1996.

167. Stephens JL, Pratt N, and Parks B. The reliability and validity of the Tekdyne hand dynamometer: Part I. J Hand Ther 9: 10-17, 1996.

168. Straub WF. Grip strength of college and professional football players. Ergonomics 22: 1185-1194, 1979.

169. Stretch R. A biomechanical analysis of the double, in: Science and Racket Sports. T Reilly, M Hughes, A Lees, eds.: Taylor \& Francis, 1994, pp 107-112.

170. Stretch RA, Bartlett R, and Davids K. A review of batting in men's cricket. $J$ Sports Sci 18: 931-949, 2000.

171. Su CY, Lin JH, Chien TH, Cheng KF, and Sung YT. Grip strength in different positions of elbow and shoulder. Arch Phys Med Rehab 75: 812-815, 1994.

172. Szymanski D, Beiser EJ, Basset K, Till ME, and Szymanski J. Relationship between sports performance variables and bat swing velocity of collegiate baseball players. J Strength Cond Res 25: S122, 2011.

173. Szymanski DJ, DeRenne C, and Spaniol FJ. Contributing factors for increased bat swing velocity. J Strength Cond Res 23: 1338-1352, 2009.

174. Szymanski DJ, McIntyre JS, Szymanski JM, Molloy JM, Madsen NH, and Pascoe DD. Effect of wrist and forearm training on linear bat-end, center of percussion, and hand velocities and on time to ball contact of high school baseball players. J Strength Cond Res 20: 231-240, 2006.

175. Szymanski DJ, Szymanski JM, Molloy JM, and Pascoe DD. Effect of 12 weeks of wrist and forearm training on high school baseball players. J Strength Cond Res 18: 432-440, 2004. 
176. Szymanski J, Szymanski D, Albert J, Reed J, Hemperley C, Hsu HS, Moore R, Potts J,

2 Turner J, and Winstead R. Relationship between physiological characteristics and baseball3 specific variables of high school baseball. J Strength Cond Res 22: 110-110, 2008.

4 177. Tajika T, Kobayashi T, Yamamoto A, Shitara H, Ichinose T, Shimoyama D, Okura C, 5 Kanazawa S, Nagai A, and Takagishi K. Relationship between grip, pinch strengths and pitchers. Asian J Sports Med 6: e25330, 2015.

178. Tan B, Aziz AR, and Chuan TK. Correlations between physiological parameters and performance in elite ten-pin bowlers. J Sci Med Sport 3: 176-185, 2000.

179. Tan B, Aziz AR, Teh KC, and Lee HC. Grip strength measurement in competitive tenpin bowlers. J Sports Med Phys Fit 41: 68-72, 2001.

180. Tong RJ and Wood GL. A comparison of upper body strength in collegiate rugby union players, in: World Congress of Science and Football. T Reilly, J Bangsbo, M Hughes, eds. Cardiff, Wales: Taylor \& Francis, 1995, pp 16-21.

181. Trossman PB and Li PW. The effect of the duration of intertrial rest periods on isometric grip strength performance in young adults. Occup Ther J Res 9: 362-378.

182. Tsakalou L, Kotsampouikidou Z, Papa M, and Zapartidis I. Handgrip strength and ball velocity of young male and female handball players

J Phys Ed Sport 15: 800-804, 2015.

183. Ulbricht A, Fernandez-Fernandez J, Mendez-Villanueva A, and Ferrauti A. Impact of fitness characteristics on tennis performance in elite junior tennis players. J Strength Cond Res 30: 989-998, 2016.

184. Verma SK. Assessment of physical variables of drag flick performance in field hockey. Int J Phys Ed 7: 78-80, 2014.

185. Wagner H, Pfusterschmied J, Tilp M, Landlinger J, von Duvillard SP, and Muller E. Upper-body kinematics in team-handball throw, tennis serve, and volleyball spike. Scand $J$ Med Sci Sports 24: 345-354, 2014.

186. Waldo BR. Grip strength testing. Strength Cond J 18: 32-35, 1996.

187. Wall CB, Starek JE, Fleck SJ, and Byrnes WC. Prediction of indoor climbing performance in women rock climbers. J Strength Cond Res 18: 77-83, 2004.

188. Ward C and Adams J. Comparative study of the test-re-test reliability of four instruments to measure grip strength in a healthy population. Br J Hand Ther 12: 48-54, 2007. 189. Wassmer DJ and Mookerjee S. A descriptive profile of elite U.S. women's collegiate field hockey players. J Sports Med Phys Fit 42: 165-171, 2002.

190. Watanabe T, Owashi K, Kanauchi Y, Mura N, Takahara M, and Ogino T. The shortterm reliability of grip strength measurement and the effects of posture and grip span. $J$ Hand Surg 30: 603-609, 2005.

191. Watts P, Newbury V, and Sulentic J. Acute changes in handgrip strength, endurance, and blood lactate with sustained sport rock climbing. J Sports Med Phys Fitness 36: 255-260, 1996.

192. Weimer B, Halet K, and Anderson T. Relationship of strength variables to bat velocity in college baseball and softball players. Missouri J Health Phys Ed Rec Dance 17: 53-59, 2007.

193. Wells GD, Elmi M, and Thomas S. Physiological correlates of golf performance. $J$ Strength Cond Res 23: 741-750, 2009.

194. Werle S, Goldhahn J, Drerup S, Simmen BR, Sprott H, and Herren DB. Age- and gender-specific normative data of grip and pinch strength in a healthy adult Swiss population. J Hand Surg Eur 34: 76-84, 2009. 
1 195. Williford H, Kirkpatrick J, Scharff-Olson M, Blessing D, and Wang N. Physical and 2 performance characteristics of successful high school football players. Am J Sports Med 22: 3 859-862, 1994.

4 196. Wimer B, Dong RG, Welcome DE, Warren C, and McDowell TW. Development of a new dynamometer for measuring grip strength applied on a cylindrical handle. Med Eng Phys 31: 695-704, 2009.

197. Wu T, Wu P, and Tsai Y. The relationship between strength, trunk rotation movements and ball speed in high school golfers. Med Sci Sports Exerc 39: S477, 2007.

198. Young RW. Evolution of the human hand: the role of throwing and clubbing. J Anat 202: 165-174, 2003.

11 199. Yu JH and Lee GC. Comparison of shoulder range of motion, strength, and endurance 12 in amateur pitchers practicing repetitive overhead throwing. Isokinet Exerc Sci 21: 135-140, 132013.

14 200. Zampagni ML, Casino D, Benelli P, Visani A, Marcacci M, and De Vito G. 15 Anthropometric and strength variables to predict freestyle performance times in elite master 16 swimmers. J Strength Cond Res 22: 1298-1307, 2008.

17 201. Zampagni ML, Casino D, Visani A, Martelli S, Benelli P, Marcacci M, and De Vito 18 G. Influence of age and hand grip strength on freestyle performances in master swimmers. 19 Presented at International Symposium on Biomechanics in Sport, Austria, 2006.

20 202. Zane L. Force Measures at the Hand-Stick Interface during Ice Hockey Slap and Wrist 21 Shots, in: Department of Physical Education and Kinesiology. Montreal, Canada: McGill, $22 \quad 2012$, p 129.

23 203. Zapartidis I, Palamas A, Papa M, Tsakalou L, and Kotsampouikidou Z. Relationship 24 among anthropometric characteristics, handgrip strength and throwing velocity in adolescent 
Table 1. Handgrip strength testing protocols

\begin{tabular}{|l|l|l|}
\hline Positions & Protocol & ICC \\
\hline Seated Positions (9, 13, & Dynamometer: hydraulic, spring, strain gauge, cylinder pneumatic, Wii balance & $0.69-0.99$
\end{tabular}
$30,34,35,38,43,46$, $65,69,84,93,98,110$, $112,119,124,127$, $140,158,167,181$, $188,190)$ board

Grip Breadth: $2^{\text {nd }}-5^{\text {th }}$ handle position $(3.89-8.58 \mathrm{~cm})$

Grip Type: Whole hand

Shoulder: i) adducted, ii) flexed at $90^{\circ}$, iii) flexed at $180^{\circ}$

Elbow: i) $90^{\circ}$ flexion, ii) extended

Forearm: i) neutral, ii) pronated, iii) supinated

Wrist: i) $0-30^{\circ}$ extension ii) neutral iii) ulnar deviation $0-15^{\circ}$; radial deviation 0 $15^{\circ}$

Trials: $1-3$ x 3-10 s MVIC per hand

Rest: $15-120$ s between trials

Output: mean and/or peak (kg, N, Pa)

Retest: 1 to 7 days to assess reliability

Standing Positions (31, $\quad$ Dynamometer: hydraulic, spring, strain gauge, pneumatic $38,66,119,125,127$, $133,171,179,190$, 196)

Grip Breadth: $2^{\text {nd }}-3^{\text {rd }}$ handle position $(4.76-6.03 \mathrm{~cm})$, cylinder, judogi sleeve

Grip type: i) whole hand, ii) middle, ring finger and thumb

Shoulder: i) adducted, ii) flexed at $90^{\circ}$, iii) flexed at $180^{\circ}$

Elbow: i) flexed at $90^{\circ}$ ii) extended,

Forearm: i) neutral, ii) pronated, iii) supinated

Wrist: $0-30^{\circ}$ extension ii) neutral

Trials: $1-3$ x 2-5 s MVIC per hand

Rest: $60-120$ s between trials

Output: peak and/or mean $(\mathrm{kg}, \mathrm{N}, \mathrm{Pa})$

Retest: 0-2 days

Supine Positions (119, $\quad$ Dynamometer: hydraulic, spring

190)

Grip Breadth: $2^{\text {nd }}-4^{\text {th }}$ handle position

Shoulder: i) adducted

Elbow: i) $90^{\circ}$ flexion, ii) extended,

Forearm: i) neutral, ii) pronated, iii) supinated

Wrist: $0-30^{\circ}$ extension

Trials: $1-3$ x 2-5 s MVIC per hand

Rest: $60 \mathrm{~s}$ between trials

Output: peak and mean (kg or N)

Retest: none

Hanging Positions ( 5 ,

Apparatus: Pull-up bar, ledge (1-4 cm), judogi sleeve, strain gauge, force plate

Grip Type: Overhand

$9,45,48,64,102)$

Grip Width: shoulder width

Shoulders: i) flexed at $180^{\circ}$; ii) flexed at $90^{\circ}$; iii) $110^{\circ}$ flexion and $60^{\circ}$ horizontal

abduction

Elbows: i) flexed at $90^{\circ}$, ii) extended, iii) flexed at $70^{\circ}$

Forearms: pronated

Wrist: i) neutral, ii) $15-30^{\circ}$ extension

Trials: i) 1-3 trials, ii) increase load in 5-10 kg increments, iii) 3 x MVIC

Rest: 0 to $90 \mathrm{~s}$

Output: i) endurance time (s), ii) maximum load (kg) $5 \mathrm{~s}$ hold, iii) maximum vertical downward force $(\mathrm{N})$

Retest: none

ICC $=$ interclass correlation coefficient MVIC = maximum voluntary isometric contraction; $\mathrm{NA}=$ not available 
Table 2. Handgrip dynamic force testing protocols

\begin{tabular}{|c|c|c|}
\hline Sport - Action & Protocol & CV\% \\
\hline $\begin{array}{l}\text { Golf - Club Swing } \\
(17,19,92,95,152)\end{array}$ & $\begin{array}{l}\text { Sensor: Tekscan } 9811 \mathrm{~F}-\mathrm{Scan}(100-264 \mathrm{~Hz}) \text {, Quantum Tunnelling composite } \\
\text { (1280 Hz), Flexiforce }(640 \mathrm{~Hz}) \text { video }(60-200 \mathrm{~Hz}) \text {, sound }(500 \mathrm{~Hz}) \\
\text { Club Specifications: 7-Iron and driver } \\
\text { Sample size range: } 2 \text { to } 28 \\
\text { Trials: } 4-10 \text { off a rubber tee or artificial turf } \\
\text { Rest: Not specified } \\
\text { Outputs: force-time signature, impact force, post-impact force, impulse } \\
\text { Retest: None } \\
\text { Reliability: Poor between subject }(\mathrm{CV}=20-70 \%) \text {, good within subject }(\mathrm{CV}< \\
10 \% \text {; ICC }>0.90) \text {. }\end{array}$ & $5-60 \%$ \\
\hline $\begin{array}{l}\text { Baseball - Bat Swing } \\
(36,123)\end{array}$ & $\begin{array}{l}\text { Sensor: strain gauge transducer (NA), video }(50 \mathrm{~Hz}) \\
\text { Bat Specifications: } 35 \mathrm{in}, 31 \mathrm{oz} \text { Easton Big Barrel aluminum bat } \\
\text { Sample size range: } 1 \\
\text { Procedures: Pitcher throws medium-fast balls at } \sim 36 \mathrm{~m} / \mathrm{s} \\
\text { Trials: Not specified } \\
\text { Rest: Not specified } \\
\text { Outputs: force-time signatures } \\
\text { Retest: None } \\
\text { Reliability: Not reported }\end{array}$ & NA \\
\hline $\begin{array}{l}\text { Cricket - Bat Swing } \\
\text { (169) }\end{array}$ & $\begin{array}{l}\text { Sensor: strain gauge transducer } \\
\text { Bat Specifications: Standard size short-handle cricket bat (Slazenger Inc.) } \\
\text { Sample size range: } 14 \\
\text { Procedures: Bowler bowls medium-fast balls at } \sim 36 \mathrm{~m} / \mathrm{s} \\
\text { Trials: Not specified } \\
\text { Rest: Not specified } \\
\text { Outputs: force-time signatures, pre-impact force, impact force, post-impact force } \\
\text { Retest: None } \\
\text { Reliability: Not reported }\end{array}$ & NA \\
\hline $\begin{array}{l}\text { Tennis - Racket Swing } \\
(89,90)\end{array}$ & $\begin{array}{l}\text { Sensor: Force sensing resistors and load cells }(1000 \text { and } 2900 \mathrm{~Hz}) \text {. } \\
\text { Racket Specifications: Midsize Pro-Kennex racket } \\
\text { Sample size range: } 7 \text { - } 12 \\
\text { Swing types: forehand and backhand } \\
\text { Trials: } 10-32 \text { strokes hit (balls projected by ball machine at } 20 \mathrm{~m} / \mathrm{s}) \\
\text { Rest: Not specified } \\
\text { Outputs: pre-impact force, impact force, post-impact force } \\
\text { Retest: None } \\
\text { Reliability: Poor within- subject reliability during the forehand }(\mathrm{CV}=21-140 \%) \text {; } \\
\text { better within-subject reliability during the backhand }(\mathrm{CV}=22-34 \%)\end{array}$ & $21-140 \%$ \\
\hline $\begin{array}{l}\text { Ice Hockey - Stick Shot } \\
\text { (202) }\end{array}$ & $\begin{array}{l}\text { Sensor: Piezoresistive sensors (1000 Hz) } \\
\text { Stick Specifications: Carbon fibre (Bauer Hockey Corp.): } 77 \text { flex, } 87 \text { flex, and } \\
102 \text { flex } \\
\text { Sample size range: } 41 \\
\text { Swing types: slap-shot and wrist-shot } \\
\text { Trials: } 5 \text { wrist shots, } 5 \text { slap shots } \\
\text { Rest: Not specified } \\
\text { Outputs: force-time signature, impact force, post-impact, impulse } \\
\text { Retest: None } \\
\text { Reliability: } \pm 10 \mathrm{~N}\end{array}$ & NA \\
\hline
\end{tabular}


Table 3. Handgrip strength differences between elite and sub-elite athletes

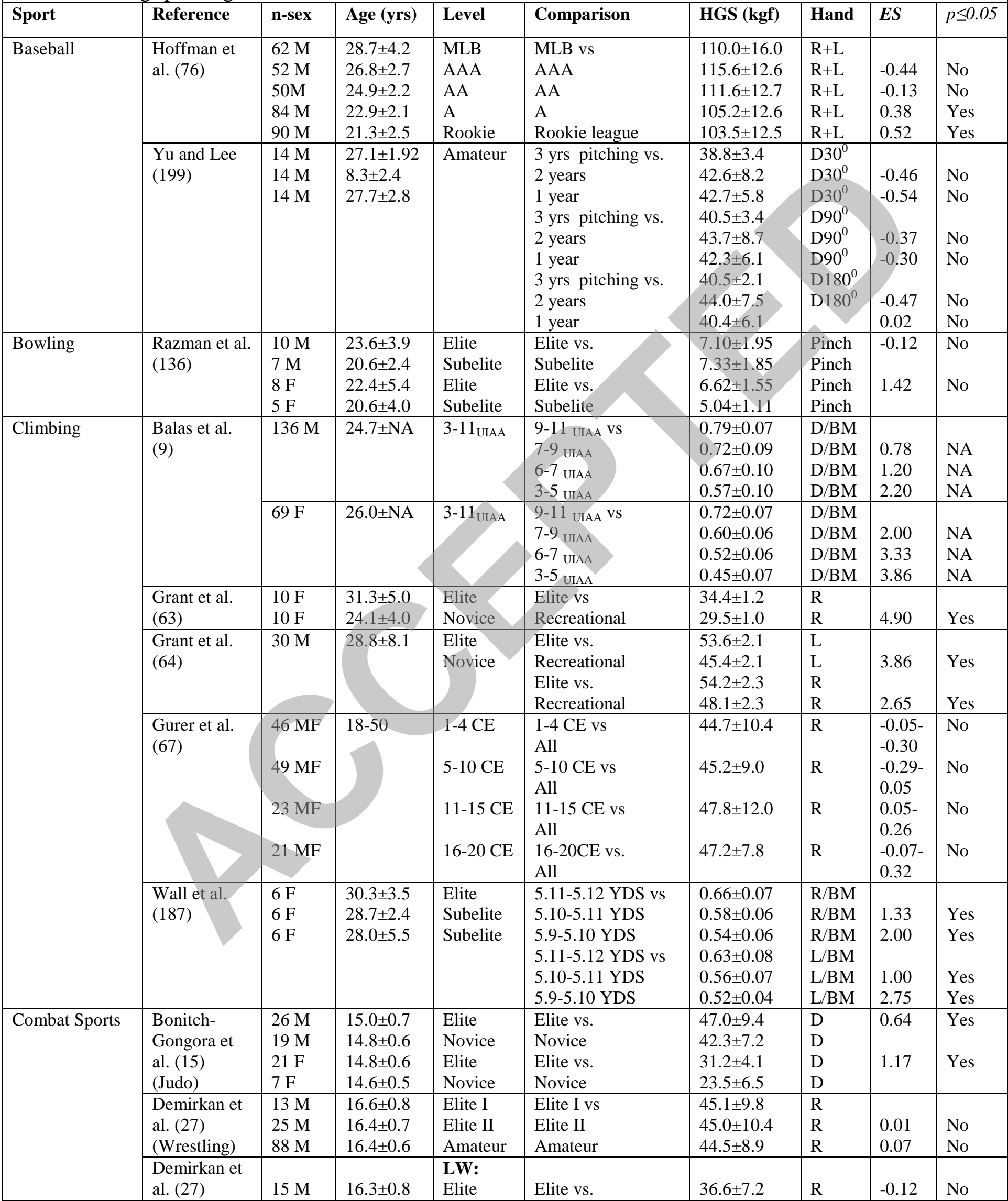




\begin{tabular}{|c|c|c|c|c|c|c|c|c|c|}
\hline & (Wrestling) & $\begin{array}{l}31 \mathrm{M} \\
12 \mathrm{M} \\
32 \mathrm{M} \\
\\
11 \mathrm{M} \\
25 \mathrm{M}\end{array}$ & $\begin{array}{l}16.2 \pm 0.7 \\
16.5 \pm 0.7 \\
16.6 \pm 0.5 \\
16.7 \pm 0.6 \\
16.6 \pm 0.6\end{array}$ & $\begin{array}{l}\text { Amateur } \\
\text { MW: } \\
\text { Elite } \\
\text { Amateur } \\
\text { HW: } \\
\text { Elite } \\
\text { Amateur }\end{array}$ & $\begin{array}{l}\text { Amateur } \\
\text { Elite vs. } \\
\text { Amateur } \\
\text { Elite vs. } \\
\text { Amateur }\end{array}$ & $\begin{array}{l}37.4 \pm 6.8 \\
47.2 \pm 5.6 \\
44.7 \pm 6.2 \\
54.1 \pm 8.2 \\
53.1 \pm 5.9\end{array}$ & $\begin{array}{l}\mathrm{R} \\
\mathrm{R} \\
\mathrm{R}\end{array}$ & 0.17 & No \\
\hline & $\begin{array}{l}\text { Demirkan et } \\
\text { al. (28) } \\
\text { (Wrestling) }\end{array}$ & $\begin{array}{l}11 \mathrm{M} \\
37 \mathrm{M}\end{array}$ & $\begin{array}{l}19.3 \pm 1.0 \\
18.8 \pm 1.0\end{array}$ & $\begin{array}{l}\text { Elite } \\
\text { Sub-elite }\end{array}$ & $\begin{array}{l}\text { Elite vs. } \\
\text { Sub-elite } \\
\text { Elite vs, } \\
\text { Sub-elite }\end{array}$ & $\begin{array}{l}54 \pm 8.0 \\
49 \pm 8.0 \\
53 \pm 7.8 \\
48 \pm 7.9\end{array}$ & $\begin{array}{l}R \\
R \\
L \\
L\end{array}$ & $\begin{array}{l}0.64 \\
0.63\end{array}$ & $\begin{array}{l}\text { No } \\
\text { No }\end{array}$ \\
\hline & $\begin{array}{l}\text { Drid et al. } \\
\text { (33) } \\
\text { (Judo) }\end{array}$ & $\begin{array}{l}5 \mathrm{M} \\
5 \mathrm{M}\end{array}$ & $\begin{array}{l}25.6 \pm 3.6 \\
25.8 \pm 4.1\end{array}$ & $\begin{array}{l}\text { Elite } \\
\text { Subelite }\end{array}$ & $\begin{array}{l}\text { Elite vs. } \\
\text { Subelite } \\
\text { Elite vs. } \\
\text { Subelite }\end{array}$ & $\begin{array}{l}64.3 \pm 1.96 \\
58.2 \pm 1.99 \\
69.0 \pm 3.74 \\
62.6 \pm 2.87\end{array}$ & $\begin{array}{l}\mathrm{L} \\
\mathrm{L} \\
\mathrm{R} \\
\mathrm{R}\end{array}$ & $\begin{array}{l}3.07 \\
2.23\end{array}$ & $\begin{array}{l}\text { No } \\
\text { No }\end{array}$ \\
\hline & $\begin{array}{l}\text { Garcia- } \\
\text { Pallares et } \\
\text { al. (56) } \\
\text { (Wrestling) }\end{array}$ & $\begin{array}{l}6 \mathrm{~F} \\
12 \mathrm{~F} \\
7 \mathrm{~F} \\
10 \mathrm{~F}\end{array}$ & $\begin{array}{l}18.2 \pm 0.8 \\
16.8 \pm 1.1 \\
18.7 \pm 1.5 \\
16.9 \pm 1.3 \\
\end{array}$ & $\begin{array}{l}\text { LW: } \\
\text { Elite } \\
\text { Amateur } \\
\text { MW: } \\
\text { Elite } \\
\text { Amateur } \\
\end{array}$ & $\begin{array}{l}\text { Elite vs. } \\
\text { Amateur } \\
\text { Elite vs. } \\
\text { Amateur }\end{array}$ & $\begin{array}{l}30.9 \pm 5.5 \\
26.9 \pm 5.4 \\
34.7 \pm 6.3 \\
32.9 \pm 3.7 \\
\end{array}$ & $\begin{array}{l}\text { D } \\
\text { D } \\
\text { D } \\
\text { D }\end{array}$ & $\begin{array}{l}0.74 \\
0.49\end{array}$ & $\begin{array}{l}\text { Yes } \\
\text { Yes }\end{array}$ \\
\hline & $\begin{array}{l}\text { Garcia- } \\
\text { Pallares et al. } \\
\text { (55) } \\
\text { (Wrestling) }\end{array}$ & $\begin{array}{l}18 \mathrm{M} \\
15 \mathrm{M} \\
\\
18 \mathrm{M} \\
19 \mathrm{M} \\
\\
10 \mathrm{M} \\
12 \mathrm{M}\end{array}$ & $\begin{array}{l}17.5 \pm 1.1 \\
16.1 \pm 1.0 \\
18.5 \pm 1.5 \\
17.1 \pm 1.8 \\
19.6 \pm 1.5 \\
17.2 \pm 1.7\end{array}$ & $\begin{array}{l}\text { LW: } \\
\text { Elite } \\
\text { Amateur } \\
\text { MW: } \\
\text { Elite } \\
\text { Amateur } \\
\text { HW: } \\
\text { Elite } \\
\text { Amateur }\end{array}$ & $\begin{array}{l}\text { Elite vs. } \\
\text { Amateur } \\
\text { Elite vs. } \\
\text { Amateur } \\
\text { Elite vs. } \\
\text { Amateur }\end{array}$ & $\begin{array}{l}45.0 \pm 6.5 \\
39.7 \pm 8.0 \\
53.1 \pm 7.8 \\
46.5 \pm 8.0 \\
55.6 \pm 8.9 \\
52.1 \pm 9.5\end{array}$ & $\begin{array}{l}\mathrm{D} \\
\mathrm{D} \\
\\
\mathrm{D} \\
\mathrm{D} \\
\\
\mathrm{D} \\
\mathrm{D}\end{array}$ & $\begin{array}{r}0.66 \\
\\
0.83 \\
0.37\end{array}$ & $\begin{array}{l}\text { Yes } \\
\text { Yes } \\
\text { No }\end{array}$ \\
\hline & $\begin{array}{l}\text { Nikooie et al. } \\
\text { (122) } \\
\text { (Wrestling) }\end{array}$ & $\begin{array}{l}5 \mathrm{M} \\
7 \mathrm{M} \\
5 \mathrm{M} \\
9 \mathrm{M}\end{array}$ & $\begin{array}{l}25.6 \pm 1.9 \\
25.5 \pm 2.5 \\
19.1 \pm 0.7 \\
18.8 \pm 0.5\end{array}$ & $\begin{array}{l}\text { Senior I } \\
\text { Senior II } \\
\text { Junior I } \\
\text { Junior II }\end{array}$ & $\begin{array}{l}\text { Medal vs. } \\
\text { No Medal } \\
\text { Medal vs. } \\
\text { No Medal }\end{array}$ & $\begin{array}{l}0.59 \pm 0.04 \\
0.52 \pm 0.06 \\
0.57 \pm 0.06 \\
0.49 \pm 0.05\end{array}$ & $\begin{array}{l}\text { D/BM } \\
\text { D/BM } \\
\text { D/BM } \\
\text { D/BM }\end{array}$ & $\begin{array}{l}1.17 \\
1.60\end{array}$ & $\begin{array}{l}\text { Yes } \\
\text { Yes }\end{array}$ \\
\hline & $\begin{array}{l}\text { Roemmich } \\
\text { and Frappier } \\
\text { (143) } \\
\text { (Wrestling) }\end{array}$ & $\begin{array}{l}19 \mathrm{M} \\
19 \mathrm{M}\end{array}$ & $\begin{array}{l}16.2 \pm 0.2 \\
16.1 \pm 0.2\end{array}$ & $\begin{array}{l}\text { High } \\
\text { school }\end{array}$ & $\begin{array}{l}\text { Winners }(84 \%) \\
\text { Losers }(64 \%)\end{array}$ & $\begin{array}{l}53.2 \pm 2.4 \\
52.8 \pm 2.2 \\
47.2 \pm 1.8 \\
45.8 \pm 2.1 \\
\end{array}$ & $\begin{array}{l}\mathrm{R} \\
\mathrm{L} \\
\mathrm{R} \\
\mathrm{L}\end{array}$ & $\begin{array}{l}3.33 \\
3.33\end{array}$ & $\begin{array}{l}\text { Yes } \\
\text { Yes }\end{array}$ \\
\hline & $\begin{array}{l}\text { Sanchez et } \\
\text { al. (148) } \\
\text { (Judo) }\end{array}$ & $71 \mathrm{M}$ & $15-19$ & State & $\begin{array}{l}\text { Gold vs } \\
\text {-Silver } \\
\text {-Bronze } \\
\text {-No medal }\end{array}$ & $\begin{array}{l}47.81 \pm 7.92 \\
52.82 \pm 8.20 \\
48.31 \pm 6.29 \\
47.32 \pm 6.00 \\
\end{array}$ & $\begin{array}{l}\text { DND } \\
\text { DND } \\
\text { DND } \\
\text { DND } \\
\end{array}$ & $\begin{array}{l}-0.61 \\
-0.08 \\
0.08\end{array}$ & $\begin{array}{l}\text { No } \\
\text { No } \\
\text { No }\end{array}$ \\
\hline & $\begin{array}{l}\text { Sanchez et } \\
\text { al. (148) } \\
\text { (Judo) }\end{array}$ & $31 \mathrm{~F}$ & $15-19$ & State & $\begin{array}{l}\text { Gold vs } \\
\text {-Silver } \\
\text {-Bronze } \\
\text {-No medal } \\
\end{array}$ & $\begin{array}{l}39.30 \pm 5.16 \\
35.85 \pm 5.30 \\
31.53 \pm 3.35 \\
30.91 \pm 2.66 \\
\end{array}$ & $\begin{array}{l}\text { DND } \\
\text { DND } \\
\text { DND } \\
\text { DND } \\
\end{array}$ & $\begin{array}{l}0.65 \\
2.32 \\
3.15 \\
\end{array}$ & $\begin{array}{l}\text { No } \\
\text { Yes } \\
\text { Yes }\end{array}$ \\
\hline Field Hockey & $\begin{array}{l}\text { Keogh et al. } \\
(87)\end{array}$ & $\begin{array}{l}35 \mathrm{~F} \\
39 \mathrm{~F}\end{array}$ & $\begin{array}{l}19.4 \pm 1.0 \\
20.3 \pm 1.5\end{array}$ & $\begin{array}{l}\text { Regional } \\
\text { Club }\end{array}$ & $\begin{array}{l}\text { Regional vs } \\
\text { Club }\end{array}$ & $\begin{array}{l}36 \pm 1 \\
34 \pm 1\end{array}$ & $\begin{array}{l}\mathrm{D} \\
\mathrm{D} \\
\end{array}$ & 2.00 & No \\
\hline & $\begin{array}{l}\text { Sharma et al. } \\
\text { (157) }\end{array}$ & $\begin{array}{l}35 \mathrm{M} \\
25 \mathrm{M}\end{array}$ & $\begin{array}{l}18-23 \\
18-23\end{array}$ & $\begin{array}{l}\text { National } \\
\text { State }\end{array}$ & $\begin{array}{l}\text { National vs } \\
\text { State } \\
\text { National vs } \\
\text { State }\end{array}$ & $\begin{array}{l}36.03 \pm 4.95 \\
36.65 \pm 3.88 \\
36.57 \pm 4.67 \\
37.77 \pm 3.40\end{array}$ & $\begin{array}{l}\mathrm{R} \\
\mathrm{R} \\
\mathrm{L} \\
\mathrm{L}\end{array}$ & $\begin{array}{l}-0.16 \\
-0.35\end{array}$ & $\begin{array}{l}\text { No } \\
\text { No }\end{array}$ \\
\hline $\begin{array}{l}\text { Football } \\
\text { (American) }\end{array}$ & $\begin{array}{l}\text { Shields et al. } \\
\text { (159) }\end{array}$ & $167 \mathrm{M}$ & $21-29$ & NFL & $\begin{array}{l}\text { Starters vs. } \\
\text {-Rookies } \\
\text {-Nonstarters }\end{array}$ & $\begin{array}{l}65.9 \pm 11.6 \\
63.6 \pm 7.1 \\
61.4 \pm 9.5\end{array}$ & $\begin{array}{l}\text { NA } \\
\text { NA } \\
\text { NA }\end{array}$ & $\begin{array}{l}0.32 \\
0.47\end{array}$ & $\begin{array}{l}\text { No } \\
\text { No }\end{array}$ \\
\hline & Straub (168) & $\begin{array}{l}28 \mathrm{M} \\
21 \mathrm{M} \\
25 \mathrm{M} \\
19 \mathrm{M} \\
\end{array}$ & $\begin{array}{l}28.2 \pm \mathrm{NA} \\
20.1 \pm \mathrm{NA}\end{array}$ & $\begin{array}{l}\text { NFL } \\
\text { College } \\
\text { NFL } \\
\text { College } \\
\end{array}$ & $\begin{array}{l}\text { NFL-offence vs. } \\
\text { College-offence } \\
\text { NFL-defence vs. } \\
\text { College-defence }\end{array}$ & $\begin{array}{l}58.59 \pm 4.66 \\
53.51 \pm 4.61 \\
58.12 \pm 6.47 \\
55.48 \pm 4.20 \\
\end{array}$ & $\begin{array}{l}\text { DND } \\
\text { DND } \\
\text { DND } \\
\text { DND }\end{array}$ & $\begin{array}{l}1.10 \\
0.63 \\
\end{array}$ & $\begin{array}{l}\text { Yes } \\
\text { No }\end{array}$ \\
\hline
\end{tabular}




\begin{tabular}{|c|c|c|c|c|c|c|c|c|c|}
\hline Handball & $\begin{array}{l}\text { Massuca et } \\
\text { al. (109) }\end{array}$ & $\begin{array}{l}41 \mathrm{M} \\
126 \mathrm{M}\end{array}$ & $\begin{array}{l}26.2 \pm 4.9 \\
25.2 \pm 4.8\end{array}$ & $\begin{array}{l}\text { Elite } \\
\text { Subelite }\end{array}$ & $\begin{array}{l}\text { Elite vs. } \\
\text { Subelite Div2/3 }\end{array}$ & $\begin{array}{l}7.21 \pm 5.99 \\
5.06 \pm 5.35\end{array}$ & $\begin{array}{l}\text { DND } \\
\text { DND }\end{array}$ & 0.22 & Yes \\
\hline Horse Riders & $\begin{array}{l}\text { Hobbs et al. } \\
\text { (75) } \\
\text { (Equestrian) }\end{array}$ & $132 \mathrm{~F}$ & $39 \pm 12$ & Leve 1-3 & $\begin{array}{l}\text { Level } 1 \text { vs } \\
\text { Level } 3 \\
\text { Level } 1 \text { vs } \\
\text { Level } 3\end{array}$ & $\begin{array}{l}25.1 \pm 8.6 \\
23.1 \pm 10.2 \\
26.0 \pm 8.9 \\
25.7 \pm 11.0\end{array}$ & $\begin{array}{l}\mathrm{L} \\
\mathrm{L} \\
\mathrm{R} \\
\mathrm{R} \\
\end{array}$ & $\begin{array}{l}0.20 \\
0.03\end{array}$ & $\begin{array}{l}\text { No } \\
\text { No }\end{array}$ \\
\hline \multirow[t]{2}{*}{ Ice Hockey } & $\begin{array}{l}\text { Peterson et } \\
\text { al.(129) }\end{array}$ & $\begin{array}{l}24 \mathrm{M} \\
11 \mathrm{M}\end{array}$ & $\begin{array}{l}18-24 \\
18-24\end{array}$ & $\begin{array}{l}\text { College } \\
\text { College }\end{array}$ & $\begin{array}{l}\text { Division I vs. } \\
\text { Division III }\end{array}$ & $\begin{array}{l}66.8 \pm 8.4 \\
56.6 \pm 8.7\end{array}$ & $\begin{array}{l}\mathrm{D} \\
\mathrm{D}\end{array}$ & 1.17 & Yes \\
\hline & $\begin{array}{l}\text { Zane, J. } \\
(202)\end{array}$ & $\begin{array}{l}21 \mathrm{M} \\
20 \mathrm{~F}\end{array}$ & $\begin{array}{l}24.3 \pm 2.8 \\
25.2 \pm 5.9 \\
25.1 \pm 6.4 \\
22.1 \pm 3.7 \\
\end{array}$ & $\begin{array}{l}\text { College } \\
\text { College }\end{array}$ & $\begin{array}{l}\text { High velocity vs } \\
\text { Low velocity } \\
\text { High velocity vs } \\
\text { Low velocity }\end{array}$ & $\begin{array}{l}44.6 \pm 5.5 \\
39.4 \pm 5.2 \\
30.5 \pm 6.3 \\
22.8 \pm 2.2 \\
\end{array}$ & $\begin{array}{l}\mathrm{D} \\
\mathrm{D} \\
\mathrm{D} \\
\mathrm{D}\end{array}$ & $\begin{array}{l}1.00 \\
3.50\end{array}$ & $\begin{array}{l}\text { Yes } \\
\text { Yes }\end{array}$ \\
\hline Rowing & Secher (156) & $\begin{array}{l}7 \mathrm{M} \\
11 \mathrm{M}\end{array}$ & $\begin{array}{l}26.0 \pm 0.6 \\
24.2 \pm 0.7\end{array}$ & $\begin{array}{l}\text { National } \\
\text { Club }\end{array}$ & $\begin{array}{l}\text { Elite vs. } \\
\text { Subelite }\end{array}$ & $\begin{array}{l}76.0 \pm 4.9 \\
67.0 \pm 2.7\end{array}$ & $\mathrm{D}$ & 3.33 & Yes \\
\hline Strength Events & $\begin{array}{l}\text { Fry et al. } \\
(52)\end{array}$ & $\begin{array}{l}20 \mathrm{M} \\
95 \mathrm{M}\end{array}$ & $14.8 \pm 2.3$ & $\begin{array}{l}\text { Weight- } \\
\text { lifters }\end{array}$ & $\begin{array}{l}\text { Elite vs. } \\
\text { Non-elite }\end{array}$ & $\begin{array}{l}52.5 \pm 8.1 \\
42.2 \pm 11.1\end{array}$ & $\begin{array}{l}\mathrm{D} \\
\mathrm{D}\end{array}$ & 0.93 & $\mathrm{Na}$ \\
\hline \multirow[t]{2}{*}{ Tennis } & $\begin{array}{l}\text { Knudson } \\
\text { (89) }\end{array}$ & $\begin{array}{l}6 \mathrm{M} \\
6 \mathrm{M}\end{array}$ & $\begin{array}{l}27 \pm 5 \\
40 \pm 9\end{array}$ & & $\begin{array}{l}\text { Advanced vs. } \\
\text { Intermediate } \\
\text { Advanced vs. } \\
\text { Intermediate }\end{array}$ & $\begin{array}{l}56.1 \pm 6.5 \\
56.8 \pm 4.9 \\
43.6 \pm 5.4 \\
39.4 \pm 6.8\end{array}$ & $\begin{array}{l}\text { ND } \\
\text { ND } \\
\text { BHG } \\
\text { BHG }\end{array}$ & $\begin{array}{l}-0.11 \\
0.77\end{array}$ & $\begin{array}{l}\text { No } \\
\text { No }\end{array}$ \\
\hline & $\begin{array}{l}\text { Ulbricht et } \\
\text { al. (183) }\end{array}$ & $\begin{array}{l}24 \mathrm{M} \\
102 \mathrm{M} \\
26 \mathrm{M} \\
229 \mathrm{M} \\
28 \mathrm{M} \\
137 \mathrm{M} \\
17 \mathrm{~F} \\
65 \mathrm{~F} \\
28 \mathrm{~F} \\
149 \mathrm{~F} \\
24 \mathrm{~F} \\
73 \mathrm{~F}\end{array}$ & $\begin{array}{l}11.5 \pm 0.3 \\
11.3 \pm 0.4 \\
13.1 \pm 0.5 \\
12.9 \pm 0.5 \\
15.0 \pm 0.5 \\
14.9 \pm 0.5 \\
11.5 \pm 0.3 \\
11.4 \pm 0.3 \\
12.9 \pm 0.5 \\
12.9 \pm 0.5 \\
14.9 \pm 0.5 \\
14.8 \pm 0.5\end{array}$ & $\begin{array}{l}\text { National } \\
\text { Region } \\
\text { National } \\
\text { Region } \\
\text { National } \\
\text { Region } \\
\text { National } \\
\text { Region } \\
\text { National } \\
\text { Region } \\
\text { National } \\
\text { Region }\end{array}$ & $\begin{array}{l}\text { U12 National vs } \\
\text { U12 Regional } \\
\text { U14 National vs } \\
\text { U14 Regional } \\
\text { U16 National vs } \\
\text { U16 Regional } \\
\text { U12 National vs } \\
\text { U12 Regional } \\
\text { U14 National vs } \\
\text { U14 Regional } \\
\text { U16 National vs } \\
\text { U16 Regional }\end{array}$ & $\begin{array}{l}24.2 \pm 3.4 \\
21.6 \pm 3.8 \\
28.6 \pm 5.6 \\
28.3 \pm 6.2 \\
43.0 \pm 7.3 \\
37.7 \pm 8.9 \\
23.2 \pm 4.1 \\
20.6 \pm 4.1 \\
29.0 \pm 5.5 \\
27.4 \pm 5.2 \\
35.3 \pm 4.4 \\
32.1 \pm 4.0\end{array}$ & $\begin{array}{l}\text { D } \\
\text { D } \\
D \\
D \\
D \\
D \\
D \\
D \\
D \\
D \\
D \\
D\end{array}$ & $\begin{array}{l}0.68 \\
0.06 \\
0.37 \\
0.64 \\
0.30\end{array}$ & $\begin{array}{l}\text { Yes } \\
\text { No } \\
\text { No } \\
\text { Yes } \\
\text { No } \\
\text { Yes }\end{array}$ \\
\hline Volleyball & $\begin{array}{l}\text { Pion et al. } \\
\text { (132) }\end{array}$ & $\begin{array}{l}13 \mathrm{~F} \\
8 \mathrm{~F}\end{array}$ & $\begin{array}{l}15.4 \pm 1.6 \\
15.1 \pm 1.4\end{array}$ & $\begin{array}{l}\text { Elite } \\
\text { Subelite }\end{array}$ & $\begin{array}{l}\text { Elite vs. } \\
\text { Subelite }\end{array}$ & $\begin{array}{l}36.7 \pm 4.9 \\
35.3 \pm 6.7\end{array}$ & $\begin{array}{l}\mathrm{D} \\
\mathrm{D}\end{array}$ & 0.21 & No \\
\hline
\end{tabular}

$\mathrm{A}=$ single A minor league baseball; $\mathrm{AA}=$ double $\mathrm{A}$ minor league baseball; $\mathrm{AAA}=$ triple $\mathrm{A}$ minor leagure baseball; $\mathrm{BHG}=$ backhand tennis stroke grip position; $\mathrm{BM}=$ body mass in $\mathrm{kg}$; $\mathrm{CE}=$ climbing experience in year; $\mathrm{D}=$ dominant hand; $\mathrm{DND}=$ mean handgrip strength of the dominant and non-dominant hands; ES = effect size; F = female subjects; HGS = handgrip strength; HW = heavy weight class; $\mathrm{L}=$ left hand; $\mathrm{LEN}=$ average ratio of 3 personal best times to the world record; $\mathrm{LW}=$ lightweight class; $\mathrm{M}=$ male subjects; $\mathrm{MLB}=$ major league baseball; $\mathrm{MW}=$ middleweight class; $\mathrm{NA}=$ information not available; $\mathrm{ND}=$ non-dominant hand; $\mathrm{NFL}=$ national football leauge; $p=$ level of significance; $\mathrm{R}=$ right hand; $\mathrm{U} 12=$ athlete under 12 years of age; $\mathrm{U} 14=$ athletes under 14 years of age; $\mathrm{U} 16=$ athletes under 16 years of age; UIAA = Union Internationale des Associations d'Alpinisme (climbing ranking system); YDS = Yosemite decimal system (climbing rankings system). 
Table 4. Relationship between sport performance measures and handgrip strength

\begin{tabular}{|c|c|c|c|c|c|c|c|c|c|c|}
\hline Sport & Reference & n-sex & Age (yrs) & Level & $\begin{array}{l}\text { Performance } \\
\text { measure }\end{array}$ & Output & HGS (kgf) & Hand & $r$ & $p \leq 0.05$ \\
\hline \multirow[t]{14}{*}{$\begin{array}{l}\text { Baseball and } \\
\text { Softball }\end{array}$} & $\begin{array}{l}\text { Albert et al. } \\
\text { (3) }\end{array}$ & $19 \mathrm{~F}$ & $19.2 \pm 1.0$ & College & BBV (mph) & NA & NA & $\mathrm{Na}$ & 0.41 & Yes \\
\hline & $\begin{array}{l}\text { Bonnette et } \\
\text { al. (16) }\end{array}$ & $23 \mathrm{M}$ & $20.6 \pm 1.3$ & College & $\begin{array}{l}\text { Bat speed (mph) } \\
\text { BBV (mph) }\end{array}$ & $\begin{array}{l}85.2 \pm 5.6 \\
83.6 \pm 6.6\end{array}$ & $60.7 \pm 8.0$ & NA & $\begin{array}{l}0.52 \\
0.50\end{array}$ & NA \\
\hline & $\begin{array}{l}\text { Fry et al. } \\
(51)\end{array}$ & $31 \mathrm{M}$ & NA & College & $\begin{array}{l}\text { Bat velocity }(\mathrm{m} / \mathrm{s}) \\
\text { Slugging \% } \\
\text { Batting average }\end{array}$ & $\begin{array}{l}37.4 \pm 3.0 \\
\text { NA } \\
\text { NA }\end{array}$ & $\begin{array}{l}49.0 \pm 8.6 \\
46.3 \pm 9.0\end{array}$ & $\begin{array}{l}\mathrm{R} \\
\mathrm{L}\end{array}$ & $\begin{array}{l}0.37 \\
0.59 \\
0.46\end{array}$ & $\begin{array}{l}\text { No } \\
\text { Yes } \\
\text { No }\end{array}$ \\
\hline & $\begin{array}{l}\text { Heitman et } \\
\text { al. (73) }\end{array}$ & $40 \mathrm{~F}$ & $21.3 \pm 3.7$ & College & $\begin{array}{l}\text { Pitch speed } \\
(\mathrm{km} / \mathrm{h})\end{array}$ & $48.1 \pm 6.0$ & $36.5 \pm 4.8$ & $\mathrm{D}$ & 0.22 & No \\
\hline & $\begin{array}{l}\text { Hoffman et } \\
\text { al. (76) }\end{array}$ & $343 \mathrm{M}$ & $21-29$ & Pro & $\begin{array}{l}\text { Home runs } \\
\text { Total bases } \\
\text { Slugging \% }\end{array}$ & $\begin{array}{l}\text { NA } \\
\text { NA } \\
\text { NA }\end{array}$ & $103-116$ & NA & $\begin{array}{l}0.32 \\
0.21 \\
0.27\end{array}$ & $\begin{array}{l}\text { Yes } \\
\text { Yes } \\
\text { Yes }\end{array}$ \\
\hline & $\begin{array}{l}\text { Hughes et } \\
\text { al. (78) }\end{array}$ & $23 \mathrm{M}$ & $19.7 \pm 1.3$ & College & Bat speed (mph) & $82.0 \pm 5.1$ & $57.0 \pm 6.7$ & NA & 0.32 & No \\
\hline & $\begin{array}{l}\text { Mangine et } \\
\text { al. (106) }\end{array}$ & $47 \mathrm{M}$ & $27.8 \pm 3.4$ & $\begin{array}{l}\text { Pro } \\
\text { (MLB) }\end{array}$ & & $98.2 \pm 1.2$ & $126 \pm 26$ & $\mathrm{R}+\mathrm{L}$ & -0.09 & No \\
\hline & $\begin{array}{l}\text { Nakata et al. } \\
(120)\end{array}$ & $164 \mathrm{M}$ & $6.4-15.7$ & Youth & $\begin{array}{l}\text { Pitching }(\mathrm{J}) \\
\text { Batting }(\mathrm{J}) \\
10 \mathrm{~m} \text { Sprint }(\mathrm{s}) \\
\mathrm{HJ}(\mathrm{m})\end{array}$ & $\begin{array}{l}26-55 \\
32-63 \\
2.17-2.49 \\
1.53-2.06\end{array}$ & $\begin{array}{l}14.3-32.1 \\
14.8-32.9\end{array}$ & $\begin{array}{l}\text { L } \\
R \\
L \\
R \\
L \\
R \\
L \\
R\end{array}$ & $\begin{array}{l}0.89 \\
0.91 \\
0.88 \\
0.90 \\
0.67 \\
0.68 \\
0.82 \\
0.84\end{array}$ & $\begin{array}{l}\text { Yes } \\
\text { Yes } \\
\text { Yes } \\
\text { Yes } \\
\text { Yes } \\
\text { Yes } \\
\text { Yes } \\
\text { Yes }\end{array}$ \\
\hline & $\begin{array}{l}\text { Pugh et al. } \\
\text { (134) }\end{array}$ & $16 \mathrm{~F}$ & $19.1 \pm 2.9$ & College & $\begin{array}{l}\text { Pitch speed } \\
(\mathrm{km} / \mathrm{h})\end{array}$ & $76.7 \pm 7.4$ & $36.6 \pm 4.1$ & $\mathrm{D}$ & 0.62 & Yes \\
\hline & $\begin{array}{l}\text { Reed et al. } \\
\text { (138) }\end{array}$ & $\begin{array}{l}47 \\
\mathrm{M} / \mathrm{F}\end{array}$ & $21.5 \pm 2.0$ & $\begin{array}{l}\text { College } \\
\text { Students }\end{array}$ & $\begin{array}{l}\text { Bat speed } \\
\text { BBV }\end{array}$ & $\begin{array}{l}\text { NA } \\
\text { NA }\end{array}$ & NA & $\begin{array}{l}\mathrm{ND} \\
\mathrm{D} \\
\mathrm{ND} \\
\mathrm{D}\end{array}$ & $\begin{array}{l}0.79 \\
0.79 \\
0.83 \\
0.85\end{array}$ & $\begin{array}{l}\text { Yes } \\
\text { Yes } \\
\text { Yes } \\
\text { Yes }\end{array}$ \\
\hline & $\begin{array}{l}\text { Spaniol et } \\
\text { al. (165) }\end{array}$ & $556 \mathrm{M}$ & $15.6 \pm 1.2$ & Youth & Bat speed (mph) & $70.3 \pm 7.1$ & $\begin{array}{l}39.3 \pm 7.9 \\
39.2 \pm 8.3\end{array}$ & $\begin{array}{l}\mathrm{R} \\
\mathrm{L} \\
\mathrm{L}+\mathrm{R}\end{array}$ & $\begin{array}{l}0.61 \\
0.61 \\
0.63\end{array}$ & $\begin{array}{l}\text { Yes } \\
\text { Yes } \\
\text { Yes }\end{array}$ \\
\hline & $\begin{array}{l}\text { Spaniol et } \\
\text { al. (164) }\end{array}$ & $34 \mathrm{M}$ & $20.6 \pm 1.3$ & College & $\begin{array}{l}\text { Bat speed (mph) } \\
\text { BBV (mph) }\end{array}$ & $\begin{array}{l}87.4 \pm 6.0 \\
78.2 \pm 4.2\end{array}$ & $61.4 \pm 8.9$ & $\mathrm{Na}$ & $\begin{array}{l}0.59 \\
0.83\end{array}$ & $\begin{array}{l}\text { Yes } \\
\text { Yes }\end{array}$ \\
\hline & $\begin{array}{l}\text { Szymanski } \\
\text { et al. (172) }\end{array}$ & $22 \mathrm{M}$ & $20.0 \pm 1.5$ & College & Bat speed (mph) & NA & NA & $\begin{array}{l}\mathrm{D} \\
\mathrm{ND}\end{array}$ & $\begin{array}{l}0.61 \\
0.59\end{array}$ & $\begin{array}{l}\text { Yes } \\
\text { Yes }\end{array}$ \\
\hline & $\begin{array}{l}\text { Szymanski } \\
\text { et al. (176) }\end{array}$ & $30 \mathrm{M}$ & $\mathrm{Na}$ & $\begin{array}{l}\text { High } \\
\text { School }\end{array}$ & $\begin{array}{l}\text { Bat speed } \\
\text { BBV }\end{array}$ & $\begin{array}{l}\text { NA } \\
\text { NA }\end{array}$ & NA & $\begin{array}{l}\text { ND } \\
\mathrm{D} \\
\mathrm{ND} \\
\mathrm{D}\end{array}$ & $\begin{array}{l}0.61 \\
0.56 \\
0.47 \\
0.42\end{array}$ & $\begin{array}{l}\text { Yes } \\
\text { Yes } \\
\text { Yes } \\
\text { Yes }\end{array}$ \\
\hline
\end{tabular}




\begin{tabular}{|c|c|c|c|c|c|c|c|c|c|c|}
\hline & $\begin{array}{l}\text { Weimer et } \\
\text { al. (192) }\end{array}$ & $\begin{array}{l}10 \mathrm{M} \\
14 \mathrm{~F}\end{array}$ & $\begin{array}{l}20.8 \pm 1.0 \\
19.5 \pm 1.1\end{array}$ & $\begin{array}{l}\text { College } \\
\text { College }\end{array}$ & $\begin{array}{l}\text { Bat speed }(\mathrm{m} / \mathrm{s}) \\
\text { Bat speed }(\mathrm{m} / \mathrm{s})\end{array}$ & $\begin{array}{l}26.0 \pm 2.8 \\
18.5 \pm 2.5\end{array}$ & \begin{tabular}{|l}
$50.2 \pm 7.8$ \\
$52.7 \pm 8.8$ \\
$31.4 \pm 7.8$ \\
$36.3 \pm 7.1$ \\
\end{tabular} & $\begin{array}{l}\mathrm{L} \\
\mathrm{R} \\
\mathrm{L} \\
\mathrm{R}\end{array}$ & $\begin{array}{l}-0.12 \\
-0.06 \\
0.38 \\
0.70 \\
\end{array}$ & $\begin{array}{l}\text { No } \\
\text { No } \\
\text { No } \\
\text { Yes } \\
\end{array}$ \\
\hline \multirow[t]{2}{*}{ Basketball } & $\begin{array}{l}\text { Lupo et el. } \\
\text { (104) }\end{array}$ & $10 \mathrm{M}$ & $22.2 \pm 4.1$ & Subelite & Free throw & NA & NA & $\mathrm{D}$ & 0.76 & Yes \\
\hline & $\begin{array}{l}\text { McGill et } \\
\text { al. (113) }\end{array}$ & $14 \mathrm{M}$ & $20.4 \pm 1.6$ & College & $\begin{array}{l}\text { Points/game } \\
\text { Assists/game } \\
\text { Rebounds/game } \\
\text { Steals/game } \\
\text { Blocks/game }\end{array}$ & $\begin{array}{l}\text { NA } \\
\text { NA } \\
\text { NA } \\
\text { NA } \\
\text { NA }\end{array}$ & $\begin{array}{l}52 \pm 9 \\
50 \pm 7\end{array}$ & $\begin{array}{l}\text { R } \\
\mathrm{L} \\
\mathrm{R} \\
\mathrm{L} \\
\mathrm{R} \\
\mathrm{L} \\
\mathrm{R} \\
\mathrm{L} \\
\mathrm{R} \\
\mathrm{L}\end{array}$ & $\begin{array}{l}-0.39 \\
-0.03 \\
-0.14 \\
-0.49 \\
-0.55 \\
0.09 \\
-0.61 \\
0.10 \\
-0.26 \\
0.18 \\
\end{array}$ & $\begin{array}{l}\text { No } \\
\text { No } \\
\text { No } \\
\text { No } \\
\text { Yes } \\
\text { No } \\
\text { Yes } \\
\text { No } \\
\text { No } \\
\text { No }\end{array}$ \\
\hline Bowling & $\begin{array}{l}\text { Tan et al. } \\
\text { (179) }\end{array}$ & $\begin{array}{l}26 \mathrm{M} \\
13 \mathrm{~F} \\
\end{array}$ & $34.3 \pm 8.2$ & Elite & Bowling score & NA & $38.1 \pm 8.8$ & $\begin{array}{l}\mathrm{D} \\
\mathrm{D}\end{array}$ & $\begin{array}{l}0.07 \\
-0.12 \\
\end{array}$ & $\begin{array}{l}\text { No } \\
\text { No }\end{array}$ \\
\hline \multirow[t]{7}{*}{ Climbing } & \multirow[t]{2}{*}{$\begin{array}{l}\text { Balas et al. } \\
\text { (9) }\end{array}$} & $136 \mathrm{M}$ & $24.7 \pm n a$ & $\begin{array}{l}\text { Novice- } \\
\text { Elite }\end{array}$ & $\begin{array}{l}\text { Redpoint scale } \\
\text { Finger hang (s) } \\
\text { Bent-arm hang (s) }\end{array}$ & $\begin{array}{l}3-12 \\
13-79 \\
30-85 \\
\end{array}$ & $42-59$ & DND & $\begin{array}{l}0.55 \\
0.53 \\
0.49 \\
\end{array}$ & NA \\
\hline & & $69 \mathrm{~F}$ & $26.0 \pm$ na & $\begin{array}{l}\text { Novice- } \\
\text { Elite }\end{array}$ & $\begin{array}{l}\text { Redpoint scale } \\
\text { Finger hang (s) } \\
\text { Bentarm hang (s) }\end{array}$ & $\begin{array}{l}3-12 \\
7-71 \\
14-69 \\
\end{array}$ & $27-44$ & DND & $\begin{array}{l}0.75 \\
0.65 \\
0.72 \\
\end{array}$ & NA \\
\hline & $\begin{array}{l}\text { Gajewski et } \\
\text { al. (53) }\end{array}$ & $21 \mathrm{M}$ & $22.0 \pm 3.4$ & & Climbing ability & $23.0 \pm 4.9$ & $\begin{array}{l}8.4 \pm 1.2 \\
\mathrm{~N} / \mathrm{kg} \\
\end{array}$ & DND & 0.56 & Yes \\
\hline & $\begin{array}{l}\text { Mermier et } \\
\text { al. (115) }\end{array}$ & $\begin{array}{l}24 \mathrm{M} \\
20 \mathrm{~F}\end{array}$ & $\begin{array}{l}30.4 \pm 6.0 \\
32.2 \pm 9.2\end{array}$ & $\begin{array}{l}5.6- \\
5.13 \mathrm{c} \\
\text { YDS }\end{array}$ & $\begin{array}{l}\text { Climbing score } \\
\text { Flexibility } \\
\text { Climbing time } \\
\text { Laps completed }\end{array}$ & & $\begin{array}{l}47.3 \pm 10.2 \\
29.4 \pm 6.0\end{array}$ & $\begin{array}{l}\mathrm{D} \\
\mathrm{D}\end{array}$ & $\begin{array}{l}0.80 \\
0.04 \\
-0.70 \\
-0.70 \\
\end{array}$ & $\begin{array}{l}\text { Yes } \\
\text { No } \\
\text { Yes } \\
\text { Yes } \\
\end{array}$ \\
\hline & $\begin{array}{l}\text { Mitchell et } \\
\text { al. (116) }\end{array}$ & $\begin{array}{l}10 \mathrm{M} \\
10 \mathrm{~F} \\
\end{array}$ & $\begin{array}{l}20.7 \pm 3.0 \\
23.2 \pm 3.8 \\
\end{array}$ & $\begin{array}{l}5.10 \mathrm{~b} \\
\text { YDS }\end{array}$ & Climbing time (s) & NA & NA & NA & $\begin{array}{l}-0.96 \\
-0.88 \\
\end{array}$ & $\begin{array}{l}\text { Yes } \\
\text { Yes } \\
\end{array}$ \\
\hline & $\begin{array}{l}\text { Wall et al. } \\
\text { (187) }\end{array}$ & $18 \mathrm{~F}$ & $28-30.3$ & $\begin{array}{l}\text { Novice } \\
\text { Expert }\end{array}$ & $\begin{array}{l}\text { Bouldering } \\
\text { Routing } \\
\text { Outdoor } \\
\text { Indoor } \\
\text { Redpoint }\end{array}$ & $\begin{array}{l}26.1-48.9 \\
7.4-37.1 \\
10.3-11.8 \\
10.4-11.6 \\
10.5-12.2\end{array}$ & $\begin{array}{l}30.5-36.3 \\
29.4-36.6 \\
0.54-0.66 \\
0.52-0.63\end{array}$ & $\begin{array}{l}\mathrm{R} \\
\mathrm{L} \\
\mathrm{R} / \mathrm{BM} \\
\mathrm{L} / \mathrm{BM} \\
\mathrm{R} \\
\mathrm{L} \\
\mathrm{R} \\
\mathrm{L} \\
\mathrm{R} \\
\mathrm{L} \\
\end{array}$ & $\begin{array}{l}0.67 \\
0.63 \\
0.50 \\
0.43 \\
0.64 \\
0.59 \\
0.50 \\
0.50 \\
0.60 \\
0.49 \\
\end{array}$ & $\begin{array}{l}\text { Yes } \\
\text { Yes } \\
\text { Yes } \\
\text { Yes } \\
\text { Yes } \\
\text { Yes } \\
\text { Yes } \\
\text { Yes } \\
\text { Yes } \\
\text { Yes }\end{array}$ \\
\hline & $\begin{array}{l}\text { Watts et al. } \\
\text { (191) }\end{array}$ & $11 \mathrm{MF}$ & $28.7 \pm 4.5$ & $\begin{array}{l}5.12 \mathrm{a} \\
\text { YDS }\end{array}$ & $\begin{array}{l}\text { Climbing time (s) } \\
\text { Number of laps }\end{array}$ & $\begin{array}{l}12.9 \pm 8.5 \\
\min \\
2.8 \pm 2.2 \\
\end{array}$ & $\begin{array}{l}\mathrm{NA} \\
\mathrm{NA} \\
\end{array}$ & $\begin{array}{l}\text { DND } \\
\text { DND }\end{array}$ & $\begin{array}{l}0.70 \\
0.70 \\
\end{array}$ & $\begin{array}{l}\text { Yes } \\
\text { Yes }\end{array}$ \\
\hline \multirow[t]{3}{*}{$\begin{array}{l}\text { Combat } \\
\text { sports }\end{array}$} & $\begin{array}{l}\text { Guidetti et } \\
\text { al. (66) }\end{array}$ & $8 \mathrm{M}$ & $22.3 \pm 1.5$ & $\begin{array}{l}\text { Boxing } \\
\text { Amateur }\end{array}$ & Ranking & NA & $58.2 \pm 6.9$ & $\mathrm{D}$ & 0.87 & Yes \\
\hline & $\begin{array}{l}\text { Franchini et } \\
\text { al. (49) }\end{array}$ & $13 \mathrm{M}$ & NA & $\begin{array}{l}\text { Judo } \\
\text { National }\end{array}$ & $\begin{array}{l}\text { Wingate power } \\
\text { Wingate work } \\
\text { Throws-30s (\#) } \\
\text { Attacks (\#) }\end{array}$ & $\begin{array}{l}8.13 \pm 0.75 \\
349 \pm 47 \\
11 \pm 1 \\
15 \pm 5 \\
\end{array}$ & $\begin{array}{l}54.3 \pm 8.3 \\
53.2 \pm 7.4\end{array}$ & $\begin{array}{l}\mathrm{R} \\
\mathrm{L}\end{array}$ & $\begin{array}{l}\mathrm{Na} \\
\mathrm{Na} \\
\mathrm{Na} \\
\mathrm{Na} \\
\end{array}$ & $\begin{array}{l}\text { No } \\
\text { No } \\
\text { No } \\
\text { No } \\
\end{array}$ \\
\hline & $\begin{array}{l}\text { Nikooie et } \\
\text { al. (122) }\end{array}$ & $\begin{array}{l}12 \mathrm{M} \\
14 \mathrm{M} \\
\end{array}$ & $\begin{array}{l}23.0-28.0 \\
18.3-19.8 \\
\end{array}$ & $\begin{array}{l}\text { Senior } \\
\text { Junior }\end{array}$ & $\begin{array}{l}\text { Performance } \\
\text { (pooled data) }\end{array}$ & $\begin{array}{l}\text { Medal vs. } \\
\text { No Medal }\end{array}$ & $\begin{array}{l}51.3 \pm 3.7 \\
46.1 \pm 3.1 \\
\end{array}$ & $\begin{array}{l}\mathrm{D} \\
\mathrm{D}\end{array}$ & 0.41 & Yes \\
\hline \multirow[t]{2}{*}{ Cricket } & $\begin{array}{l}\text { Amritashish } \\
\text { and Shiny } \\
\text { (6) }\end{array}$ & $15 \mathrm{M}$ & $20.7 \pm 1.8$ & Academy & Spin-off score & NA & $44.9 \pm 4.6$ & $\mathrm{D}$ & 0.03 & No \\
\hline & $\begin{array}{l}\text { Sathya, et } \\
\text { al. (149) }\end{array}$ & $75 \mathrm{~m}$ & $17-19$ & College & $\begin{array}{l}2 \mathrm{~kg} \text { D medicine } \\
\text { ball putt }(\mathrm{m})\end{array}$ & $12.35 \pm 1.9$ & $\begin{array}{l}34.6 \pm 6.5 \\
33.4 \pm 5.6 \\
\end{array}$ & $\begin{array}{l}\mathrm{D} \\
\mathrm{ND}\end{array}$ & 0.65 & Yes \\
\hline Equestrian & Keeton (85) & $56 \mathrm{~F}$ & 19.8 & College & Points & NA & 28.8 & $\mathrm{R}$ & 0.21 & No \\
\hline
\end{tabular}




\begin{tabular}{|c|c|c|c|c|c|c|c|c|c|c|}
\hline & & & & & & & 27.2 & $\mathrm{~L}$ & 0.09 & No \\
\hline \multirow[t]{3}{*}{ Field Hockey } & $\begin{array}{l}\text { Sharma et } \\
\text { al. (157) }\end{array}$ & 更 & 18-23 & State & $\begin{array}{l}\mathrm{VO}_{2} \max \\
\text { Slalom sprint (s) } \\
\text { Dribble test (s) } \\
\mathrm{VO}_{2} \max \\
\text { Slalom sprint (s) } \\
\text { Dribble test (s) }\end{array}$ & $\begin{array}{l}45.2 \pm 2.2 \\
17.5 \pm 1.6 \\
18.3 \pm 1.6 \\
44.4 \pm 2.0 \\
17.5 \pm 2.0 \\
18.4 \pm 1.8\end{array}$ & $\begin{array}{l}36.0 \pm 5.0 \\
36.6 \pm 4.7\end{array}$ & $\begin{array}{l}\text { R } \\
\mathrm{L} \\
\mathrm{R} \\
\mathrm{L} \\
\mathrm{R} \\
\mathrm{L} \\
\mathrm{R} \\
\mathrm{L} \\
\mathrm{R} \\
\mathrm{L} \\
\mathrm{R} \\
\mathrm{L}\end{array}$ & $\begin{array}{l}0.16 \\
0.19 \\
0.01 \\
0.06 \\
0.01 \\
0.08 \\
0.02 \\
-0.00 \\
-0.01 \\
0.09 \\
-0.10 \\
-0.01\end{array}$ & $\begin{array}{l}\text { No } \\
\text { No } \\
\text { No } \\
\text { No } \\
\text { No } \\
\text { No } \\
\text { No } \\
\text { No } \\
\text { No } \\
\text { No } \\
\text { No } \\
\text { No }\end{array}$ \\
\hline & $\begin{array}{l}\text { Verma } \\
(184)\end{array}$ & $30 \mathrm{M}$ & NA & National & Drag flick ability & NA & NA & NA & 0.45 & Yes \\
\hline & $\begin{array}{l}\text { Wassmer } \\
\text { and } \\
\text { Mookerjee } \\
(189)\end{array}$ & $37 \mathrm{~F}$ & $20.2 \pm 1.5$ & College & $\begin{array}{l}\text { Hitting power (s) } \\
\text { Hitting accuracy } \\
\text { Pushing power (s) } \\
\text { Pushing accuracy }\end{array}$ & $\begin{array}{l}7.70 \pm 1.75 \\
22.1 \pm 6.3 \\
9.41 \pm 1.06 \\
16.6 \pm 7.0\end{array}$ & & $\begin{array}{l}\mathrm{R} \\
\mathrm{L} \\
\mathrm{R} \\
\mathrm{L} \\
\mathrm{R} \\
\mathrm{L} \\
\mathrm{R} \\
\mathrm{L}\end{array}$ & \begin{tabular}{l|}
0.04 \\
0.13 \\
-0.09 \\
-0.11 \\
-0.12 \\
-0.10 \\
-0.13 \\
-0.05
\end{tabular} & $\begin{array}{l}\text { No } \\
\text { No } \\
\text { No } \\
\text { No } \\
\text { No } \\
\text { No } \\
\text { No } \\
\text { No }\end{array}$ \\
\hline \multirow[t]{3}{*}{$\begin{array}{l}\text { Football } \\
\text { (American) }\end{array}$} & $\begin{array}{l}\text { Agbuga, et } \\
\text { al. (2) }\end{array}$ & $41 \mathrm{M}$ & $20.6 \pm 2.1$ & College & Bench Press 1RM & $124 \pm 24$ & $57.2 \pm 8.9$ & $\mathrm{D}$ & 0.25 & No \\
\hline & Straub (168) & $40 \mathrm{M}$ & $20.1 \pm \mathrm{NA}$ & College & $\begin{array}{l}\text { Player Ranking: } \\
\text { Wide receiver } \\
\text { Defensive end } \\
\text { Defensive tackle } \\
\text { Secondary } \\
\text { Offensive tackle } \\
\text { Guard } \\
\text { Offensive back }\end{array}$ & NA & $\begin{array}{l}54.5-56.6 \\
52.5-54.3\end{array}$ & $\begin{array}{l}\text { D } \\
\text { ND } \\
\text { D } \\
\text { ND } \\
\text { D } \\
\text { ND } \\
\text { D } \\
\text { ND } \\
\text { D } \\
\text { ND } \\
\text { D } \\
\text { ND } \\
\text { D } \\
\text { ND }\end{array}$ & $\begin{array}{l}-0.20 \\
-0.10 \\
-0.25 \\
-0.30 \\
-0.70 \\
-0.10 \\
-0.40 \\
-0.60 \\
0.60 \\
0.00 \\
-0.50 \\
-0.50 \\
0.03 \\
-0.26\end{array}$ & NA \\
\hline & Straub (168) & & $28.2 \pm \mathrm{NA}$ & $\begin{array}{l}\text { Elite } \\
\text { (NFL) }\end{array}$ & $\begin{array}{l}\text { Player Ranking: } \\
\text { Wide receiver } \\
\text { Defensive end } \\
\text { Defensive tackle } \\
\text { Linebacker } \\
\text { Secondary } \\
\text { Offensive tackle } \\
\text { Guard } \\
\text { Offensive back }\end{array}$ & NA & $\begin{array}{l}60.0-61.7 \\
55.5-56.1\end{array}$ & $\begin{array}{l}\text { D } \\
\text { ND } \\
\text { D } \\
\text { ND } \\
\text { D } \\
\text { ND } \\
\text { D } \\
\text { ND } \\
\text { D } \\
\text { ND } \\
\text { D } \\
\text { ND } \\
\text { D } \\
\text { ND } \\
\text { D } \\
\text { ND }\end{array}$ & $\begin{array}{l}-0.30 \\
0.00 \\
-0.60 \\
0.00 \\
0.40 \\
-0.60 \\
0.15 \\
-0.04 \\
-0.04 \\
0.27 \\
0.12 \\
0.12 \\
0.43 \\
0.34 \\
-0.21 \\
0.26\end{array}$ & NA \\
\hline $\begin{array}{l}\text { Football } \\
\text { (Soccer) }\end{array}$ & $\begin{array}{l}\text { James et al. } \\
(80)\end{array}$ & $60 \mathrm{M}$ & $13.8 \pm 1.3$ & Club & $\begin{array}{l}5 \mathrm{~m} \text { sprint (s) } \\
\text { T-Test (s) }\end{array}$ & NA & NA & $\begin{array}{l}\text { DND } \\
\text { DND }\end{array}$ & $\begin{array}{l}-0.73 \\
-0.40\end{array}$ & $\begin{array}{l}\text { Yes } \\
\text { Yes }\end{array}$ \\
\hline
\end{tabular}




\begin{tabular}{|c|c|c|c|c|c|c|c|c|c|c|}
\hline \multirow[t]{3}{*}{ Golf } & $\begin{array}{l}\text { Brown et al. } \\
\text { (18) }\end{array}$ & $16 \mathrm{~F}$ & $24.8 \pm 7.3$ & Elite & Club speed $(\mathrm{m} / \mathrm{s})$ & $39.5 \pm 2.5$ & $\begin{array}{l}32.9 \pm 5.3 \\
33.3 \pm 5.9\end{array}$ & $\begin{array}{l}\mathrm{L} \\
\mathrm{R}\end{array}$ & $\begin{array}{l}0.54 \\
\text { NA }\end{array}$ & $\begin{array}{l}\text { Yes } \\
\text { No }\end{array}$ \\
\hline & $\begin{array}{l}\text { Hellstrom } \\
\text { (74) }\end{array}$ & $30 \mathrm{M}$ & $18-30$ & Elite & Club speed $(\mathrm{m} / \mathrm{s})$ & $49.8 \pm 2.7$ & $\begin{array}{l}52.2 \pm 8.7 \\
55.0 \pm 7.7\end{array}$ & $\begin{array}{l}\mathrm{L} \\
\mathrm{R}\end{array}$ & $\begin{array}{l}0.31 \\
0.36\end{array}$ & $\begin{array}{l}\text { No } \\
\text { Yes }\end{array}$ \\
\hline & $\begin{array}{l}\text { Wells et al. } \\
\text { (193) }\end{array}$ & $\begin{array}{l}15 \mathrm{M} \\
9 \mathrm{~F}\end{array}$ & $22.7 \pm 5.1$ & Elite & $\begin{array}{l}\text { Driver ball speed } \\
(\mathrm{km} / \mathrm{h}) \\
\text { Driver distance } \\
(\mathrm{m}) \\
5 \text { Iron ball speed } \\
(\mathrm{km} / \mathrm{h}) \\
5 \mathrm{Iron} \text { distance } \\
(\mathrm{m}) \\
\text { Score } \\
\text { (shots/round) } \\
\text { Greens in } \\
\text { regulation } \\
\text { Putt distance after } \\
\text { chip (feet) } \\
\text { Putts per round }\end{array}$ & $\begin{array}{l}245 \pm 28 \\
224 \pm 31 \\
198 \pm 18 \\
166 \pm 18 \\
73.2 \pm 2.4 \\
12 \pm 1.5 \\
8.4 \pm 1.7 \\
30.8 \pm 1.8\end{array}$ & $\begin{array}{l}46.2 \pm 11.9 \\
45.8 \pm 12.2\end{array}$ & $\begin{array}{l}\mathrm{D} \\
\mathrm{ND} \\
\mathrm{D} \\
\mathrm{ND} \\
\mathrm{D} \\
\mathrm{ND} \\
\mathrm{D} \\
\mathrm{ND} \\
\mathrm{D} \\
\mathrm{ND} \\
\mathrm{D} \\
\mathrm{ND} \\
\mathrm{D} \\
\mathrm{ND} \\
\mathrm{D} \\
\mathrm{ND}\end{array}$ & \begin{tabular}{l|l|}
0.78 \\
0.82 \\
0.77 \\
0.81 \\
0.78 \\
0.85 \\
0.78 \\
0.85 \\
-0.68 \\
-0.71 \\
0.31 \\
0.21 \\
-0.23 \\
-0.36 \\
-0.31 \\
-0.44
\end{tabular} & $\begin{array}{l}\text { Yes } \\
\text { Yes } \\
\text { Yes } \\
\text { Yes } \\
\text { Yes } \\
\text { Yes } \\
\text { Yes } \\
\text { Yes } \\
\text { Yes } \\
\text { Yes } \\
\text { No } \\
\text { No } \\
\text { No } \\
\text { No } \\
\text { No } \\
\text { Yes }\end{array}$ \\
\hline Gymnastics & $\begin{array}{l}\text { Ruprai et al. } \\
(146)\end{array}$ & $25 \mathrm{M}$ & $22.0 \pm 2.0$ & NA & $\begin{array}{l}\text { HGS endurance } \\
\text { (s) }\end{array}$ & $32.3 \pm 6.9$ & $61.1 \pm 7.2$ & $\mathrm{D}$ & 0.82 & Yes \\
\hline \multirow[t]{3}{*}{ Handball } & $\begin{array}{l}\text { Phulkar } \\
(131)\end{array}$ & NA & $18-22$ & Institute & $\begin{array}{l}\text { Handball ability } \\
\text { Handball ability }\end{array}$ & NA & NA & $\begin{array}{l}\mathrm{R} \\
\mathrm{L}\end{array}$ & $\begin{array}{l}0.78 \\
0.68\end{array}$ & $\begin{array}{l}\text { Yes } \\
\text { Yes }\end{array}$ \\
\hline & $\begin{array}{l}\text { Tsakalou et } \\
\text { al. (182) }\end{array}$ & $\begin{array}{l}16 \mathrm{M} \\
17 \mathrm{~F} \\
58 \mathrm{M} \\
30 \mathrm{~F} \\
\end{array}$ & $\begin{array}{l}12.6 \\
12.5 \\
13.5 \\
13.5 \\
\end{array}$ & Club & $\begin{array}{l}\text { Ball speed }(\mathrm{km} / \mathrm{h}) \\
\text { Ball speed }(\mathrm{km} / \mathrm{h}) \\
\text { Ball speed }(\mathrm{km} / \mathrm{h}) \\
\text { Ball speed }(\mathrm{km} / \mathrm{h})\end{array}$ & $\begin{array}{l}60.8 \\
55.8 \\
67.8 \\
55.8 \\
\end{array}$ & $\begin{array}{l}29.0 \\
25.4 \\
39.8 \\
27.4 \\
\end{array}$ & $\begin{array}{l}\mathrm{D} \\
\mathrm{D} \\
\mathrm{D} \\
\mathrm{D} \\
\end{array}$ & $\begin{array}{l}0.59 \\
0.59 \\
0.70 \\
0.70 \\
\end{array}$ & $\begin{array}{l}\text { Yes } \\
\text { Yes }\end{array}$ \\
\hline & $\begin{array}{l}\text { Zapartidis et } \\
\text { al. (203) }\end{array}$ & $\begin{array}{l}75 \mathrm{M} \\
44 \mathrm{~F} \\
\end{array}$ & $13.4 \pm 0.4$ & Club & $\begin{array}{l}\text { Ball speed }(\mathrm{km} / \mathrm{h}) \\
\text { Ball speed }(\mathrm{km} / \mathrm{h})\end{array}$ & $\begin{array}{l}67.5 \pm 7.3 \\
56.5 \pm 5.1 \\
\end{array}$ & $\begin{array}{l}39.8 \pm 8.1 \\
30.7 \pm 0.1 \\
\end{array}$ & $\begin{array}{l}\mathrm{D} \\
\mathrm{D}\end{array}$ & $\begin{array}{l}0.68 \\
0.68\end{array}$ & Yes \\
\hline \multirow[t]{2}{*}{ Ice Hockey } & $\begin{array}{l}\text { Alexander } \\
\text { et al. (4) }\end{array}$ & $30 \mathrm{M}$ & NA & Elite & $\begin{array}{l}\text { Slap shot speed } \\
\text { Wrist shot speed } \\
\text { Slap-shot accur. } \\
\text { Wrist-shot accur. }\end{array}$ & $\begin{array}{l}120-140 \\
112-127 \\
19-23 / 30 \\
18-21 / 30\end{array}$ & $\begin{array}{l}\text { NA } \\
\text { NA }\end{array}$ & $\begin{array}{l}\mathrm{D} \\
\mathrm{D} \\
\mathrm{D} \\
\mathrm{D}\end{array}$ & $\begin{array}{l}0.25 \\
0.10 \\
0.16 \\
0.09\end{array}$ & $\begin{array}{l}\text { No } \\
\text { No } \\
\text { No } \\
\text { No }\end{array}$ \\
\hline & $\begin{array}{l}\text { Zane, J. } \\
(202)\end{array}$ & $\begin{array}{l}21 \mathrm{M} \\
20 \mathrm{~F}\end{array}$ & $\begin{array}{l}24.3 \pm 2.8 \\
25.1 \pm 6.4\end{array}$ & $\begin{array}{l}\text { College } \\
\text { College }\end{array}$ & $\begin{array}{l}\text { Slap shot }(\mathrm{km} / \mathrm{h}) \\
\text { Wrist shot }(\mathrm{km} / \mathrm{h}) \\
\text { Slap shot }(\mathrm{km} / \mathrm{h}) \\
\text { Wrist shot }(\mathrm{km} / \mathrm{h})\end{array}$ & $\begin{array}{l}106.6 \pm 4.8 \\
85.9 \pm 5.9 \\
78.9 \pm 8.0 \\
63.0 \pm 6.1 \\
\end{array}$ & $\begin{array}{l}44.6 \pm 5.5 \\
30.5 \pm 6.3\end{array}$ & $\begin{array}{l}\mathrm{D} \\
\mathrm{D} \\
\mathrm{D} \\
\mathrm{D}\end{array}$ & $\begin{array}{l}0.49 \\
0.51 \\
0.75 \\
0.69 \\
\end{array}$ & $\begin{array}{l}\text { Yes } \\
\text { Yes } \\
\text { Yes } \\
\text { Yes } \\
\end{array}$ \\
\hline Lacrosse & $\begin{array}{l}\text { Marsh et al. } \\
\text { (107) }\end{array}$ & $15 \mathrm{~F}$ & $20.3 \pm 1.7$ & College & $\begin{array}{l}\text { Shot accuracy } \\
(\mathrm{cm}) \\
\text { Shot velocity } \\
(\mathrm{m} / \mathrm{s}) \\
\text { Balance }\end{array}$ & $\begin{array}{l}15.2 \pm 4.3 \\
17.1 \pm 5.4 \\
1.56-10.59\end{array}$ & $34.5 \pm 5.6$ & $\begin{array}{l}\mathrm{D} \\
\mathrm{D} \\
\mathrm{D}\end{array}$ & $\begin{array}{l}0.19 \\
0.13 \\
<0.25\end{array}$ & $\begin{array}{l}\text { No } \\
\text { No } \\
\text { No }\end{array}$ \\
\hline $\begin{array}{l}\text { Mountain } \\
\text { Bike }\end{array}$ & $\begin{array}{l}\text { Chidley et } \\
\text { al. (22) }\end{array}$ & $43 \mathrm{na}$ & $25 \pm 5$ & $\begin{array}{l}\text { Novice } \\
\text { to Elite }\end{array}$ & Ride time (s) & $214 \pm 34$ & $41.6 \pm 8.1$ & DND & 0.87 & Yes \\
\hline \multirow[t]{2}{*}{$\begin{array}{l}\text { Paddle } \\
\text { Sports }\end{array}$} & $\begin{array}{l}\text { Hamano et } \\
\text { al. (68) }\end{array}$ & $\begin{array}{l}11 \mathrm{M} \\
12 \mathrm{M}\end{array}$ & $\begin{array}{l}20.6 \pm 0.9 \\
19.7 \pm 1.2\end{array}$ & $\begin{array}{l}\text { Canoe } \\
\text { Kayak }\end{array}$ & $\begin{array}{l}\text { Ergometer power } \\
\text { Ergometer power }\end{array}$ & $\begin{array}{l}183 \pm 48 \\
347 \pm 55\end{array}$ & $\begin{array}{l}50.0 \pm 11.5 \\
50.6 \pm 7.9\end{array}$ & $\begin{array}{l}\text { D } \\
\text { D }\end{array}$ & $\begin{array}{l}0.75 \\
0.64\end{array}$ & $\begin{array}{l}\text { Yes } \\
\text { Yes }\end{array}$ \\
\hline & $\begin{array}{l}\text { Secher } \\
(156)\end{array}$ & $40 \mathrm{M}$ & $24-26$ & $\begin{array}{l}\text { Row } \\
\text { National }\end{array}$ & $\begin{array}{l}\text { Rowing strength } \\
(\mathrm{Kp})\end{array}$ & $162-204$ & $67-76$ & $\begin{array}{l}\text { NA } \\
\text { NA }\end{array}$ & 0.43 & Yes \\
\hline Rugby & $\begin{array}{l}\text { Tong and } \\
\text { Wood (180) }\end{array}$ & $30 \mathrm{M}$ & NA & College & $\begin{array}{l}\text { Bench press 1RM } \\
\text { Bench pull 1RM } \\
\text { Arm curl 1RM }\end{array}$ & $\begin{array}{l}100-114 \\
87-98 \\
54-61\end{array}$ & $\begin{array}{l}60.4-67.5 \\
58.1-63.7\end{array}$ & $\begin{array}{l}\text { R } \\
\text { L } \\
\text { R } \\
\text { L } \\
\text { R } \\
\text { L }\end{array}$ & $\begin{array}{l}0.46 \\
0.57 \\
0.57 \\
0.55 \\
0.54 \\
0.58\end{array}$ & $\begin{array}{l}\text { Yes } \\
\text { Yes } \\
\text { Yes } \\
\text { Yes } \\
\text { Yes } \\
\text { Yes }\end{array}$ \\
\hline
\end{tabular}




\begin{tabular}{|c|c|c|c|c|c|c|c|c|c|c|}
\hline \multirow[t]{6}{*}{ Swimming } & $\begin{array}{l}\text { Blanksby et } \\
\text { al. (12) }\end{array}$ & $82 \mathrm{MF}$ & $9-13$ & State & $\begin{array}{l}100 \text { m freestyle } \\
\text { (ratio to record) } \\
100 \text { Butterfly } \\
\text { (ratio to record) }\end{array}$ & $\begin{array}{l}\text { NA } \\
\text { NA }\end{array}$ & $\begin{array}{l}\text { NA } \\
\text { NA }\end{array}$ & $\begin{array}{l}\text { NA } \\
\text { NA }\end{array}$ & $\begin{array}{l}-0.36 \\
-0.38\end{array}$ & $\begin{array}{l}\text { No } \\
\text { No }\end{array}$ \\
\hline & $\begin{array}{l}\text { Douda et al. } \\
\text { (32) }\end{array}$ & $\begin{array}{l}30 \mathrm{MF} \\
42 \mathrm{MF} \\
72 \mathrm{MF}\end{array}$ & $\begin{array}{l}10.5 \pm 0.5 \\
13.7 \pm 1.5 \\
10.5-13.7\end{array}$ & $\begin{array}{l}\text { Pre-pub. } \\
\text { Pubertal } \\
\text { Pooled }\end{array}$ & $\begin{array}{l}50 \mathrm{~m} \text { freestyle }(\mathrm{s}) \\
50 \mathrm{~m} \text { freestyle }(\mathrm{s}) \\
50 \mathrm{~m} \text { freestyle }(\mathrm{s})\end{array}$ & $\begin{array}{l}\text { NA } \\
\text { NA } \\
\text { NA }\end{array}$ & $\begin{array}{l}8.9 \pm 3.4 \\
16.3 \pm 7.8 \\
\text { NA }\end{array}$ & $\begin{array}{l}\mathrm{R} \\
\mathrm{R} \\
\mathrm{R}\end{array}$ & $\begin{array}{l}-0.41 \\
-0.54 \\
-0.60\end{array}$ & $\begin{array}{l}\text { Yes } \\
\text { Yes } \\
\text { Yes }\end{array}$ \\
\hline & $\begin{array}{l}\text { Garrido et } \\
\text { al. (57) }\end{array}$ & $\begin{array}{l}10 \mathrm{~F} \\
14 \mathrm{~F} \\
15 \mathrm{~F} \\
11 \mathrm{M} \\
10 \mathrm{M} \\
18 \mathrm{M}\end{array}$ & $\begin{array}{l}12.5 \pm 0.5 \\
14.6 \pm 0.5 \\
18.6 \pm 2.3 \\
15.0 \pm 0.5 \\
16.4 \pm 0.5 \\
21.8 \pm 2.3\end{array}$ & $\begin{array}{l}\text { Pubertal } \\
\text { Teens } \\
\text { Senior } \\
\text { Teens I } \\
\text { Teens II } \\
\text { Senior }\end{array}$ & $\begin{array}{l}100 \mathrm{~m} \text { freestyle } \\
200 \mathrm{~m} \text { freestyle } \\
100 \mathrm{~m} \text { freestyle } \\
200 \mathrm{~m} \text { freestyle } \\
100 \mathrm{~m} \text { freestyle } \\
200 \mathrm{~m} \text { freestyle } \\
100 \mathrm{~m} \text { freestyle } \\
200 \mathrm{~m} \text { freestyle } \\
100 \mathrm{~m} \text { freestyle } \\
200 \mathrm{~m} \text { freestyle } \\
100 \mathrm{~m} \text { freestyle } \\
200 \mathrm{~m} \text { freestyle }\end{array}$ & $\begin{array}{l}\text { NA } \\
\text { NA } \\
\text { NA } \\
\text { NA } \\
\text { NA } \\
\text { NA }\end{array}$ & $\begin{array}{l}32.8 \pm 5.5 \\
30.9 \pm 4.3 \\
33.5 \pm 5.9 \\
46.6 \pm 9.7 \\
48.1 \pm 7.7\end{array}$ & $\begin{array}{l}\text { D } \\
\text { D } \\
\text { D } \\
\text { D } \\
\text { D }\end{array}$ & \begin{tabular}{l|}
0.82 \\
0.65 \\
0.62 \\
0.21 \\
0.54 \\
0.59 \\
0.63 \\
-0.01 \\
0.49 \\
-0.18 \\
0.31 \\
0.26 \\
\end{tabular} & $\begin{array}{l}\text { Yes } \\
\text { Yes } \\
\text { Yes } \\
\text { No } \\
\text { Yes } \\
\text { Yes } \\
\text { Yes } \\
\text { No } \\
\text { No } \\
\text { No } \\
\text { No } \\
\text { No }\end{array}$ \\
\hline & $\begin{array}{l}\text { Geladas et } \\
\text { al. (58) }\end{array}$ & $\begin{array}{l}178 \mathrm{M} \\
85 \mathrm{~F}\end{array}$ & $12-14$ & Youth & $\begin{array}{l}100 \mathrm{~m} \text { freestyle }(\mathrm{s}) \\
100 \mathrm{~m} \text { freestyle }(\mathrm{s})\end{array}$ & $\begin{array}{l}65.5 \pm 0.25 \\
68.1 \pm 0.22 \\
\end{array}$ & $\begin{array}{l}34.0 \pm 0.6 \\
28.2 \pm 0.6 \\
\end{array}$ & $\begin{array}{l}\text { DND } \\
\text { DND }\end{array}$ & $\begin{array}{l}-0.73 \\
-0.18 \\
\end{array}$ & $\begin{array}{l}\text { Yes } \\
\text { No }\end{array}$ \\
\hline & $\begin{array}{l}\text { Saavedra et } \\
\text { al. (147) }\end{array}$ & $\begin{array}{l}66 \mathrm{M} \\
67 \mathrm{~F} \\
\end{array}$ & $\begin{array}{l}13.6 \pm 0.6 \\
11.5 \pm 0.6 \\
\end{array}$ & National & $\begin{array}{l}\text { LEN } 800 \mathrm{~m} \\
\text { LEN }(100-800 \mathrm{~m})\end{array}$ & $\begin{array}{l}508 \pm 71 \\
476 \pm 76\end{array}$ & $\begin{array}{l}28.7 \pm 6.8 \\
15.9 \pm 4.2 \\
\end{array}$ & $\begin{array}{l}\text { NA } \\
\text { NA }\end{array}$ & $\begin{array}{l}0.51 \\
0.54 \\
\end{array}$ & $\begin{array}{l}\text { NA } \\
\text { NA }\end{array}$ \\
\hline & $\begin{array}{l}\text { Zampagni et } \\
\text { al. (200) }\end{array}$ & $\begin{array}{l}135 \\
\mathrm{M} / \mathrm{F}\end{array}$ & $40-80$ & Elite & $\begin{array}{l}50 \mathrm{~m} \text { freestyle } \\
100 \mathrm{~m} \text { freestyle } \\
200 \mathrm{~m} \text { freestyle } \\
400 \mathrm{~m} \text { freestyle } \\
800 \mathrm{~m} \text { freestyle }\end{array}$ & $\begin{array}{l}34.4 \pm 5.8 \\
69.8 \pm 9.1 \\
164 \pm 28 \\
359 \pm 90 \\
716 \pm 109 \\
\end{array}$ & $36-44$ & $\mathrm{D}$ & $\begin{array}{l}-0.72 \\
-0.57 \\
-0.58 \\
-0.57 \\
-0.39\end{array}$ & $\begin{array}{l}\text { Yes } \\
\text { Yes } \\
\text { Yes } \\
\text { Yes } \\
\text { Yes }\end{array}$ \\
\hline \multirow[t]{2}{*}{$\begin{array}{l}\text { Strength } \\
\text { Events }\end{array}$} & $\begin{array}{l}\text { Fry et al. } \\
(52)\end{array}$ & $\begin{array}{l}20 \mathrm{M} \\
95 \mathrm{M}\end{array}$ & $14.8 \pm 2.3$ & $\begin{array}{l}\text { Elite } \\
\text { Subelite }\end{array}$ & $\begin{array}{l}\text { 1RM Snatch } \\
\text { 1RM Clean\&Jerk } \\
\text { 1RM Snatch } \\
\text { 1RM Clean\&Jerk }\end{array}$ & $\begin{array}{l}95.6 \pm 14.8 \\
125 \pm 20 \\
62.1 \pm 23.9 \\
82 \pm 31 \\
\end{array}$ & $\begin{array}{l}52.5 \pm 8.1 \\
42.2 \pm 11.1\end{array}$ & $\begin{array}{l}\mathrm{D} \\
\mathrm{D}\end{array}$ & 0.38 & NA \\
\hline & $\begin{array}{l}\text { Schoffstall } \\
\text { et al. (153) }\end{array}$ & $3 \mathrm{~F}$ & $\begin{array}{l}25 \pm 9 \\
33 \pm 13\end{array}$ & State & $\begin{array}{l}\text { 1RM squat } \\
\text { 1RM bench press } \\
\text { 1RM deadlift } \\
\text { 1RM squat } \\
\text { 1RM bench press } \\
\text { 1RM deadlift }\end{array}$ & $\begin{array}{l}200 \pm 30 \\
119 \pm 21 \\
212 \pm 51 \\
41 \pm 6 \\
50 \pm 9 \\
88 \pm 13\end{array}$ & $\begin{array}{l}63.0 \pm 10.0 \\
64.2 \pm 8.7 \\
33.8 \pm 6.9 \\
37.0 \pm 3.7\end{array}$ & $\begin{array}{l}\mathrm{R} \\
\mathrm{L} \\
\mathrm{R} \\
\mathrm{L}\end{array}$ & $\begin{array}{l}0.97 \\
0.98 \\
0.97 \\
0.97 \\
0.98 \\
0.97\end{array}$ & $\begin{array}{l}\text { Yes } \\
\text { Yes } \\
\text { Yes } \\
\text { Yes } \\
\text { Yes } \\
\text { Yes }\end{array}$ \\
\hline \multirow[t]{3}{*}{ Tennis } & $\begin{array}{l}\text { Cohen et al. } \\
\text { (24) }\end{array}$ & $40 \mathrm{M}$ & $33.7 \pm 7.1$ & Elite & Serve speed & NA & NA & $\mathrm{D}$ & $<0.30$ & No \\
\hline & $\begin{array}{l}\text { Girard \& } \\
\text { Miller (61) }\end{array}$ & $12 \mathrm{M}$ & $13.6 \pm 1.4$ & Junior & $\begin{array}{l}\text { Player ranking } \\
5 \mathrm{~m} \text { sprint (s) } \\
10 \mathrm{~m} \text { sprint (s) } \\
20 \mathrm{~m} \text { sprint (s) } \\
\mathrm{SJ}(\mathrm{W} / \mathrm{kg}) \\
\mathrm{CMJ}(\mathrm{W} / \mathrm{kg}) \\
\text { DJ (W/kg) }\end{array}$ & $\begin{array}{l}\text { Scale } \\
1.19 \pm 0.07 \\
2.02 \pm 0.14 \\
3.55 \pm 0.27 \\
34.1 \pm 8.0 \\
33.0 \pm 13.1 \\
22.1 \pm 4.3\end{array}$ & $\begin{array}{l}17.6 \pm 6.4 \\
14.5 \pm 4.8\end{array}$ & $\begin{array}{l}\mathrm{D} \\
\mathrm{ND} \\
\mathrm{D} \\
\mathrm{ND} \\
\mathrm{D} \\
\mathrm{ND} \\
\mathrm{D} \\
\mathrm{ND} \\
\mathrm{D} \\
\mathrm{ND} \\
\mathrm{D} \\
\mathrm{ND} \\
\mathrm{D} \\
\mathrm{ND} \\
\end{array}$ & $\begin{array}{l}-0.67 \\
-0.29 \\
-0.77 \\
-0.67 \\
-0.77 \\
-0.67 \\
-0.76 \\
-0.55 \\
0.77 \\
0.63 \\
0.83 \\
0.72 \\
0.59 \\
0.41 \\
\end{array}$ & $\begin{array}{l}\text { Yes } \\
\text { No } \\
\text { Yes } \\
\text { Yes } \\
\text { Yes } \\
\text { Yes } \\
\text { Yes } \\
\text { Yes } \\
\text { Yes } \\
\text { Yes } \\
\text { Yes } \\
\text { Yes } \\
\text { No } \\
\text { No }\end{array}$ \\
\hline & $\begin{array}{l}\text { Pugh et al. } \\
\text { (133) }\end{array}$ & $15 \mathrm{M}$ & $20.8 \pm 2.0$ & College & Ball speed $(\mathrm{km} / \mathrm{h})$ & $173.8 \pm 6.4$ & $55.1 \pm 9.7$ & $\mathrm{D}$ & 0.41 & No \\
\hline
\end{tabular}




\begin{tabular}{|c|c|c|c|c|c|c|c|c|c|c|}
\hline & $\begin{array}{l}\text { Roetert et } \\
\text { al. (144) }\end{array}$ & $83 \mathrm{M}$ & $11.6 \pm 0.6$ & Junior & $\begin{array}{l}\text { Ranking } \\
\text { Service } \\
\text { Forehand. } \\
\text { Backhand } \\
\text { Push up (reps) } \\
\text { CMJ (m) } \\
\text { Sit \& reach (m) } \\
\text { Response time (s) }\end{array}$ & $\begin{array}{l}\text { NA } \\
\text { NA } \\
\text { NA } \\
\text { NA } \\
26.5 \pm 9.0 \\
0.37 \pm 0.06 \\
0.58 \pm 0.52 \\
0.37 \pm 0.06\end{array}$ & $\begin{array}{l}22.0 \pm 5.8 \\
18.4 \pm 5.1\end{array}$ & $\begin{array}{l}\mathrm{D} \\
\mathrm{ND} \\
\mathrm{D} \\
\mathrm{D} \\
\mathrm{D} \\
\mathrm{ND} \\
\mathrm{D} \\
\mathrm{ND} \\
\mathrm{D} \\
\mathrm{ND} \\
\mathrm{D} \\
\mathrm{ND} \\
\mathrm{D} \\
\mathrm{ND}\end{array}$ & $\begin{array}{l}0.02 \\
0.02 \\
0.32 \\
0.18 \\
0.17 \\
0.32 \\
0.25 \\
0.19 \\
0.28 \\
0.34 \\
0.15 \\
0.19 \\
0.26 \\
0.21\end{array}$ & $\begin{array}{l}\text { No } \\
\text { No } \\
\text { No } \\
\text { No } \\
\text { No } \\
\text { No } \\
\text { Yes } \\
\text { No } \\
\text { Yes } \\
\text { Yes } \\
\text { No } \\
\text { No } \\
\text { Yes } \\
\text { No }\end{array}$ \\
\hline & $\begin{array}{l}\text { Smart et.a } \\
\text { al. (161) }\end{array}$ & $35 \mathrm{MF}$ & $25.2 \pm 7.0$ & $\begin{array}{l}\text { College } \\
\text { Subelite }\end{array}$ & $\begin{array}{l}\text { Serve velocity } \\
(\mathrm{m} / \mathrm{s})\end{array}$ & NA & $\mathrm{NA}$ & $\mathrm{D}$ & 0.66 & Yes \\
\hline & $\begin{array}{l}\text { Ulbricht et } \\
\text { al. (183) }\end{array}$ & $\begin{array}{l}902 \\
\mathrm{MF}\end{array}$ & $11-16$ & Junior & $\begin{array}{l}\text { Ranking U12 } \\
\text { Ranking U14 } \\
\text { Ranking U16 }\end{array}$ & NA & $\begin{array}{l}20.6-24.2 \\
27.4-29.0 \\
32.1-43.0\end{array}$ & $\begin{array}{l}\text { D } \\
\text { D } \\
\text { D }\end{array}$ & $\begin{array}{l}<0.24 \\
<0.30 \\
<0.39\end{array}$ & $\begin{array}{l}\text { No } \\
\text { No } \\
\text { No }\end{array}$ \\
\hline \multirow[t]{2}{*}{ Volleyball } & $\begin{array}{l}\text { Kilic and } \\
\text { Binboga } \\
(88)\end{array}$ & $\begin{array}{l}69 \mathrm{~F} \\
44 \mathrm{M}\end{array}$ & $15-17$ & $\begin{array}{l}\text { High } \\
\text { School }\end{array}$ & $\begin{array}{l}\text { Vertical jump (m) } \\
\text { Leg strength (kg) }\end{array}$ & $\begin{array}{l}0.45-0.58 \\
91-139\end{array}$ & $\begin{array}{l}29.0-43.4 \\
\text { (pooled) } \\
28.2-40.8 \\
\text { (pooled) }\end{array}$ & $\begin{array}{l}\mathrm{R} \\
\mathrm{L} \\
\mathrm{R} \\
\mathrm{L}\end{array}$ & $\begin{array}{l}0.65 \\
0.56 \\
0.67 \\
0.61\end{array}$ & $\begin{array}{l}\text { Yes } \\
\text { Yes } \\
\text { Yes } \\
\text { Yes }\end{array}$ \\
\hline & $\begin{array}{l}\text { Melrose et } \\
\text { al. (114) }\end{array}$ & $29 \mathrm{~F}$ & $14.3 \pm 1.4$ & Club & $\begin{array}{l}\text { Serve velocity } \\
(\mathrm{m} / \mathrm{s})\end{array}$ & $16.1 \pm 2.5$ & $34.5 \pm 5.5$ & $\mathrm{D}$ & 0.60 & NA \\
\hline \multirow[t]{5}{*}{ Water polo } & $\begin{array}{l}\text { Abraldes et } \\
\text { al. (1) }\end{array}$ & $30 \mathrm{M}$ & NA & Elite & $\begin{array}{l}\text { Throwing velocity } \\
(\mathrm{m} / \mathrm{s})\end{array}$ & NA & NA & D & 0.36 & Yes \\
\hline & $\begin{array}{l}\text { Ferragut et } \\
\text { al.(40) }\end{array}$ & $\begin{array}{l}94 \mathrm{M} \\
20 \mathrm{M} \\
45 \mathrm{M}\end{array}$ & $24.5 \pm 5.3$ & $\begin{array}{l}\text { Elite: } \\
\text {-Centres } \\
\text {-Wings } \\
\text {-Centres } \\
\text {-Wings } \\
\end{array}$ & $\begin{array}{l}\text { No goalkeep: } \\
\text { Throwing velocity } \\
\text { Throwing velocity } \\
\text { With goalkeep: } \\
\text { Throwing velocity } \\
\text { Throwing velocity } \\
\end{array}$ & $\begin{array}{l}21.4 \pm 4.4 \\
21.3 \pm 3.7 \\
\\
20.8 \pm 4.6 \\
20.8 \pm 3.6 \\
\end{array}$ & $\begin{array}{l}58.6 \pm 5.4 \\
55.0 \pm 5.6 \\
\\
58.6 \pm 5.4 \\
55.0 \pm 5.6 \\
\end{array}$ & $\begin{array}{l}\mathrm{D} \\
\mathrm{D} \\
\\
\mathrm{D} \\
\mathrm{D}\end{array}$ & $\begin{array}{l}0.50 \\
\text { NA } \\
\\
\text { NA } \\
0.38 \\
\end{array}$ & $\begin{array}{l}\text { Yes } \\
\text { No } \\
\text { No } \\
\text { Yes }\end{array}$ \\
\hline & $\begin{array}{l}\text { Ferragut et } \\
\text { al. (41) }\end{array}$ & $19 \mathrm{M}$ & $24.0 \pm 5.1$ & $\begin{array}{l}\text { National } \\
\text { team }\end{array}$ & $\begin{array}{l}\text { Throwing speed } \\
(\mathrm{km} / \mathrm{h})\end{array}$ & $72.3 \pm 3.5$ & $47.7 \pm 6.7$ & D & 0.50 & Yes \\
\hline & $\begin{array}{l}\text { Ferragut et } \\
\text { al. (42) }\end{array}$ & $13 \mathrm{M}$ & $26.1 \pm 4.8$ & Elite & $\begin{array}{l}\text { Throwing velocity } \\
(\mathrm{m} / \mathrm{s})\end{array}$ & $20.5 \pm 1.2$ & $44.2 \pm 6.6$ & $\mathrm{D}$ & 0.60 & Yes \\
\hline & $\begin{array}{l}\text { Martinez et } \\
\text { al. (108) }\end{array}$ & $46 \mathrm{~F}$ & $22.5 \pm 5.1$ & Elite & $\begin{array}{l}\text { Throwing velocity } \\
(\mathrm{m} / \mathrm{s})\end{array}$ & $14.8-17.3$ & $25.3-37.4$ & D & NA & No \\
\hline \multicolumn{11}{|c|}{$\begin{array}{l}\mathrm{BBV}=\text { batted-ball velocity; } \mathrm{BM}=\text { body mass in } \mathrm{kg} ; \mathrm{CMJ}=\text { countermovment jump; } \mathrm{D}=\text { dominant hand; } \mathrm{DJ}=\text { drop jump; } \mathrm{F}=\text { female } \\
\text { subjects; FINA = swim times converted to FINA points in comparison to the world record; } \mathrm{FEV}=\text { force expiratory volume; } \mathrm{FIV}=\text { forced } \\
\text { inspiratory volume; } \mathrm{HGS}=\mathrm{Handgrip} \text { strength; } \mathrm{HJ}=\text { horizontal jump; } \mathrm{HW}=\text { heavy weight class; } \mathrm{L}=\text { left hand; } \mathrm{LEN}=\text { average ratio of } 3 \\
\text { personal best times to the world record; } \mathrm{LW}=\text { light weight class; } \mathrm{M}=\text { male subjects; } \mathrm{MLB}=\text { major league baseball; } \mathrm{MW}=\text { middle weight } \\
\text { class; } \mathrm{NA}=\text { information not available; } \mathrm{ND}=\text { non-dominant hand; } \mathrm{NFL}=\text { national football league; } p=\text { level of significance; } \mathrm{R}=\text { right hand; } \\
r=\text { Pearson product moment correlation; } \mathrm{SJ}=\text { squat jump; } \mathrm{U} 12=\text { athlete under } 12 \text { years of age; } \mathrm{U} 14=\text { athletes under } 14 \text { years of age; } \mathrm{U} 16= \\
\text { athletes under } 16 \text { years of age; } \mathrm{VO}_{2} \text { max = maximum volume of oxygen comsumed; YDS = Yosemite decimal system (climbing rankings } \\
\text { system). }\end{array}$} \\
\hline
\end{tabular}

